\title{
Toward Natural Born Derivative Citizenship
}

\author{
John Vlahoplus*
}

\begin{abstract}
Senator Ted Cruz's campaign for the Republican presidential nomination again raised the question whether persons who receive citizenship at birth to American parents abroad are natural born and eligible to the presidency. This article uses Supreme Court decisions and previously overlooked primary source material from the Founders, the First Congress and English and British law to show that they are not natural born under the doctrinal or historical meaning of the term. The relevant constitutional distinction is between citizenship acquired by birth or by naturalization, not at birth or afterward.

It argues further that a living constitutional theory cannot justifiably interpret the term more broadly because derivative citizenship statutes have long discriminated on grounds including race, gender, sexual orientation, and marital and socioeconomic status. The Supreme Court upholds them even though they would be unacceptable if applied to citizens because they merely discriminate against aliens. Moreover, many who assert presidential eligibility or other constitutional privilege for children born to American parents abroad intend to favor traditionally dominant groups or rely on political theories of bloodline transmission of national character that the Supreme Court used to justify its infamous decision in Dred Scott v. Sandford. No justifiable living interpretation can incorporate such discrimination or discredited political theories in qualifications for the highest office in the land.

The article examines the meaning of the term "natural born" in the broader context of similar discrimination in English and British law from which American law developed. It acknowledges the difficulty of reconciling centuries of derivative nationality law and practice with our highest constitutional ideals of equal protection of the law. It concludes by identifying threshold requirements for and a possible approach to developing a justifiable living constitutional interpretation of natural born derivative citizenship.
\end{abstract}

\section{KEYWORDS}

Constitutional Law, Presidential Eligibility, Natural Born Citizen, Legal History, Fourteenth Amendment.

\section{CONTENTS}

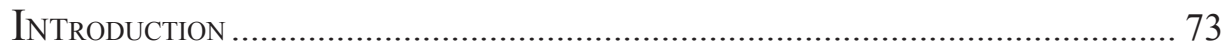

I. Ineligibility of Derivative Citizens ................................................. 75

A. U.S. Citizenship .................................................................... 76

B. Natural Born Citizenship "By Birth" .............................................. 76

C. Citizenship "By Naturalization” ................................................ 78

* Member, New York State Bar. I am grateful to the Editor, staff and anonymous referees of the British Journal of American Legal Studies for their insightful criticisms and editorial support. 


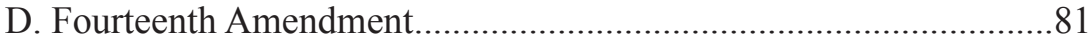

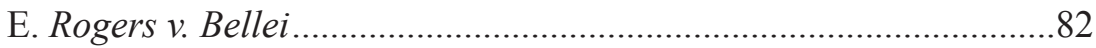

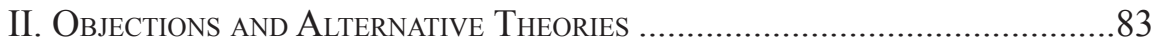

A. Alleged Opacity and Ambiguity of the Term "Natural Born Citizen"...83

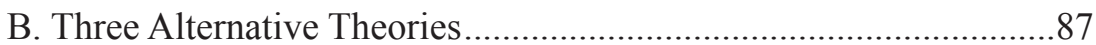

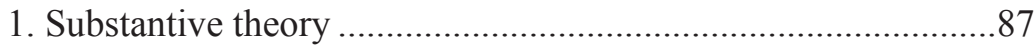

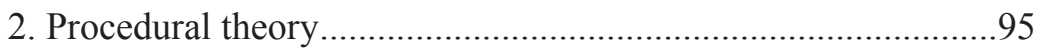

a. Supreme Court precedents ......................................................96

b. Constitutional history and structure .....................................97

c. The Naturalization Act of 1790 .............................................99

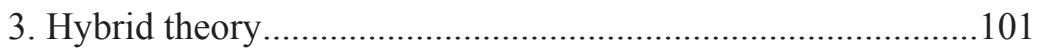

III. Consistency with English AND British Interpretations ....................104

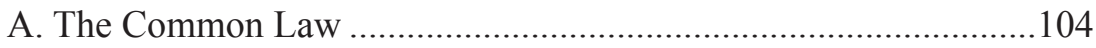

B. Naturalization and Non-transmission of Nationality .....................105

C. Inconsistencies in English and British Interpretations ...................106

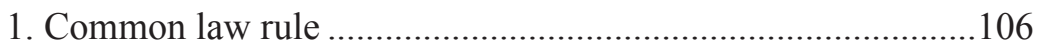

2. Effect of post-natal naturalization ............................................107

3. Operation and effects of the Acts .............................................108

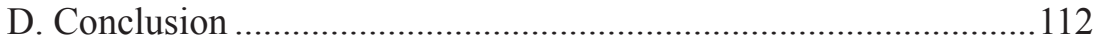

IV. Natural Born Derivative Citizenship: Threshold

Requirements AND a Possible ApProach.................................. 113 


\section{INTRODUCTION}

"He cannot be a subject born of one kingdom that was born under the ligiance of a king of another kingdom. 18.a." Thomas Jefferson, Notes on British and American Alienage, [1783 $]^{1}$

"A person born out of the jurisdiction of the United States can only become a citizen by being naturalized, . . . as in the enactments conferring citizenship upon foreign-born children of citizens ...." United States $v$. Wong Kim Ark, 169 U.S. 649, $702-03$ (1898)

"Citizenship obtained through naturalization ... carries with it all of the rights and prerogatives of citizenship obtained by birth in this country 'save that of eligibility to the Presidency." Knauer v. United States, 328 U.S. $654,658(1946)^{2}$

Senator Ted Cruz's campaign for the Republican presidential nomination again highlighted the Constitution's natural born citizenship requirement for presidential eligibility. ${ }^{3}$ Sen. Cruz was born out of the jurisdiction of the United States. ${ }^{4}$ An act of Congress conferred citizenship upon him as the foreign-born child of a citizen parent. $^{5}$ Therefore under U.S. constitutional history and Supreme Court doctrine Sen. Cruz is a naturalized citizen who has all of the rights obtained by birth in the United States except presidential eligibility. ${ }^{6}$

Some legal scholars consider the doctrinal and historical meaning of the term "natural born" to be outdated and suggest that judges could interpret it more broadly to include persons who receive citizenship under congressional statutes because of their birth to American parents abroad ("derivative citizenship"). ${ }^{7}$

1 National Archives [1783], http://founders.archives.gov/documents/ Jefferson/01-06-02-0346. Jefferson's citation is to Coke's report of the decision in Calvin v. Smith (1608) 7 Co. Rep. 1a, 77 Eng. Rep. 377, 2 St. Tr. 560 [hereinafter Calvin's Case], http://hdl.handle.net/2027/nyp.33433009487145. Coke's report "is the earliest, most influential theoretical articulation by an English court of what came to be the commonlaw rule that a person's status was vested at birth, and based upon place of birth" and "became the basis of the American common-law rule of birthright citizenship ...." Polly J. Price, Natural Law and Birthright Citizenship in Calvin's Case (1608), 9 YAle J.L. \& Human. 73, 74 (1997) (citation omitted). For Coke's definition of a "subject born" and equating it with a "natural born subject" see Calvin's Case, 7 Co. Rep. at 18 a.

2 Quoting Luria v. United States, 231 U.S. 9, 22 (1913).

3 U.S. Const. art. II, § 1, cl. 5.

4 See Response of Senator Cruz to Petitions at 2, In re Petition of Elliott, Petition of Booth, and Petition of Laity, The State of New Hampshire Ballot Law Commission (Nov. 20, 2015), http://sos.nh.gov/WorkArea/DownloadAsset.aspx?id=8589951054 [hereinafter Response].

5 Id. at 23-24.

6 See, e.g., Mary Brigid McManamon, The Natural Born Citizen Clause as Originally Understood, 64 CATH. U.L. Rev. 317 (2015) and Brief Amicus Curiae of Prof. Einer Elhauge on the Justiciability and Meaning of the Natural Born Citizen Requirement 13 (March 22, 2016), https://ssrn.com/abstract $=2748863$.

7 See, e.g., Laurence H. Tribe, Under Ted Cruz's own logic, he's ineligible for the White House, Boston Globe(Jan. 11,2016), https://www.bostonglobe.com/opinion/2016/01/11/ 
These suggestions are problematic because derivative citizenship statutes have long discriminated on grounds including race, gender, sexual orientation, and marital and socioeconomic status. ${ }^{8}$ The Supreme Court upholds them even though they "would be unacceptable if applied to citizens" because they merely discriminate against aliens. ${ }^{9}$ Moreover, some who assert presidential eligibility for children born to citizens abroad intend to favor traditionally dominant groups. Chief Justice Fuller asserted in his Wong Kim Ark dissent that foreign-born children of American citizens must be natural born because "it is unreasonable to conclude that" children born in the United States "of the Mongolian, Malay or other race" are eligible to be president, but "children of our citizens, born abroad," are not. ${ }^{10}$ Finally, many of those who assert presidential eligibility or other constitutional privilege for children born to citizens abroad rely on the same political theories of bloodline transmission of national character that the Supreme Court used to justify its infamous decision in Dred Scott v. Sandford, ${ }^{11}$ that Chief Justice Fuller cited to oppose Wong Kim Ark's citizenship, ${ }^{12}$ that nativists rely on to oppose birthright citizenship for children born in America to unlawfully resident aliens,$^{13}$ and that "birthers" cited to dispute President Obama's eligibility to the

through-ted-cruz-constitutional-looking-glass/zvKE6qpF31q2RsvPO9nGoK/story. html. Citizenship can derive in other circumstances, e.g. by the naturalization of a minor's parent.

8 See, e.g., Kristin A. Collins, Illegitimate Borders: Jus Sanguinis Citizenship and the Legal Construction of Family, Race, and Nation, 123 YALE L.J. 2134 (2014), and M. Isabel Medina, Derivative Citizenship: What's Marriage, Citizenship, Sex, Sexual Orientation, Race, and Class Got to do With It?, 28 Geo. Immig. L.J. 391 (2014).

9 See Mathews v. Diaz, 426 U.S. 67, 79-80 (1976). See also Demore v. Kim, 538 U.S. 510, 521 (2003), and Miller v. Albright, 523 U.S. 420, 434 n.11 (1998) (application to derivative citizenship). $C f$. Michael McFarland, Derivative Citizenship: Its History, Constitutional Foundation, and Constitutional Limitations, 63 N.Y.U. AnN. Surv. Ам. L. 467, 468 (2008). This article was written before the Supreme Court's decision in Sessions v. Morales-Santana, 582 U.S. _ (2017). That decision held a derivative citizenship statute to be unconstitutional on the ground of gender discrimination. However, the Court declined to recognize the child's citizenship as a remedy for the constitutional violation.

10 United States v. Wong Kim Ark, 169 U.S. 649, 714-15 (1898) (Fuller, C.J., dissenting).

1160 U.S. 363, 403 (1856) (Taney, C.J.) (limiting opinion to persons descended from imported slaves) and 477 (Daniel, J., concurring) (citing de Vattel to conclude that a child cannot be a citizen if born in the country to a foreigner). For reliance on bloodline transmission of nationality to justify presidential eligibility and other constitutional privilege, see, e.g., supra note 10 and accompanying text (presidential eligibility) and Miller, 523 U.S. at 477, 480 (Breyer, J., dissenting) (citing Roman law and de Vattel to justify a higher level of equal protection scrutiny for the derivative citizenship claim of a foreign-born "American child of American parents"). See also the American (Know Nothing) Party's view that children born to "American parents residing temporarily abroad, should be entitled to all the rights of native-born citizens." American Platform of Principles, The True American's Almanac And Politician's Manual For 1857 (1857), http://glc.yale.edu/american-platform-principles.

12 See Wong Kim Ark, 169 U.S. at 708-10 (Fuller, C.J., dissenting) (citing de Vattel).

13 See, e.g., T.L. Coston, Arizona to Deny Anchor Babies Birth Certificates, Coston's COMPLAINT (June 23, 2010), http://costonscomplaint.blogspot.com/2010/06/arizona-todeny-anchor-babies-birth.html. 
presidency. ${ }^{14}$ No justifiable living or responsive constitutional interpretation can incorporate such discrimination or discredited political theories in qualifications for the highest office in the land. This article details the historical and doctrinal exclusion of those born to citizen parents abroad from natural born citizenship in the context of similar discrimination in English and British law from which it developed. ${ }^{15}$ The article concludes by identifying threshold requirements for and a possible approach to developing a justifiable theory of natural born derivative citizenship.

\section{Ineligibility of Derivative Citizens}

The Constitution recognizes two types of citizens, natural born and naturalized. ${ }^{16}$ Only natural born citizens are eligible to the presidency. ${ }^{17}$ Although the Supreme Court has not considered a challenge to presidential eligibility, it has long held that derivative citizens are naturalized and that naturalized citizens are not natural born. ${ }^{18}$ Therefore derivative citizens are ineligible. ${ }^{19}$ The Court's rulings and American constitutional history reflect the following principles.

14 See, e.g., Mario Apuzzo, Emer de Vattel, Adolf Hitler, America's Youth, and the Natural Born Citizen Clause (Dec. 11, 2011), http://puzo1.blogspot.com/2011/12/emer-devattel-adolf-hitler-americas.html.

15 This article utilizes historical materials up to the debates and actions of the First Congress as well as later writings of the Founders to determine the historical constitutional meaning of the term. It uses judicial decisions beyond that period to determine the doctrinal meaning because the doctrinal theory of interpretation treats judicial decisions as accretive and is not limited to judgments from a particular period. For a general discussion of the two methods of interpretation see, e.g., Robert C. Post, Theories of Constitutional Interpretation, 30 Representations 13, 20-22 (1990). Parts I and II discuss the controlling American interpretations of the original English and British sources. Part III considers their consistency with English and British interpretations of those sources. The article does not comprehensively consider lower court cases; to the extent they are inconsistent with Supreme Court precedents, the latter control. The article cites only lower court decisions of special interest in understanding the Supreme Court's controlling doctrine.

16 See U.S. Const. art. II, § 1, cl. 5 (natural born citizen) and art. I, § 8, cl. 4 (enumerated congressional power to enact a uniform rule of naturalization). See also U.S. Const. amend. XIV, Wong Kim Ark, 169 U.S. at 702 and Minor v. Happersett, 88 U.S. 162, 167 (1875).

17 See U.S. Const. art. II, § 1, cl. 5.

18 See infra notes 30-33 (derivative citizens are naturalized) and 21-24 (naturalized citizens are not natural born). The Court did tangentially consider presidential eligibility in oral argument in Montana v. Kennedy, 366 U.S. 308 (1961). Counsel for Montana, who was born in Italy, argued that some statutes confer naturalized citizenship and others natural born citizenship. Justice Frankfurter asked "[y]ou mean a child born in Italy could become the President under this?" and counsel for Montana replied "I -- I think we 're going to have to have you interpret that", eliciting hearty laughter. The Court rejected Montana's claim to citizenship. Oral argument at 28:23, 28:36, 28:45 and 1:56:13, Montana v. Kennedy, 366 U.S. 308 (1961), https://www.oyez.org/cases/1960/198.

19 See, e.g., Knauer v. United States, 328 U.S. 654, 658 (1946) (naturalized citizenship does not confer presidential eligibility). 


\section{A. U.S. CITIZENSHIP}

There are only two ways to obtain U.S. citizenship, by birth and by naturalization. ${ }^{20}$ The two are distinct. ${ }^{21}$ As John Jay stated the principle in 1781, "a person may by Birth or admission become a Citizen ....,22

\section{B. NATURAL Born CitIZENShiP "By Birth"}

Citizenship "by birth" is obtained by birth within and under the jurisdiction of the United States. ${ }^{23}$ It is birthright "natural born" citizenship under the Constitution as recognized by Justice Curtis in dissent in Dred Scott v. Sandford and by the Court in Minor v. Happersett, Elk v. Wilkins, United States v. Wong Kim Ark, and Perkins v. Elg, the only Supreme Court case declaring a person to be a natural born citizen and directing the federal government to treat her as such. ${ }^{24}$ The Constitution

See, e.g., Minor, 88 U.S. at 167.

21 See, e.g., Elk v. Wilkins, 112 U.S. 94, 101 (1884).

22 See Letter from John Jay to Benjamin Franklin, National Archives (May 31, 1781) (regarding state citizenship prior to the adoption of the Constitution), http://founders. archives.gov/documents/Franklin/01-35-02-0082. State citizenship then was primary. See, e.g., James H. Kettner, The Development of American Citizenship, 1608-1870, at 219-21 (1978).

23 See, e.g., United States v. Wong Kim Ark, 169 U.S. 649, 702-03 (1898) ("citizenship by birth is established by the mere fact of birth . . . in the United States, and subject to the jurisdiction thereof . . . ."); Inglis v. Trustees of Sailor's Snug Harbor, 28 U.S. 99, 155 (1830) (Story, J., dissenting on other grounds) ("allegiance by birth, is that which arises from being born within the dominions and under the protection of a particular sovereign."), quoted and relied upon by Wong Kim Ark, 169 U.S. at 659; and McKay v. Campbell, 16 F.Cas. 161, 165 (D. Ore. 1871) ("To be a citizen of the United States by reason of his birth, a person must not only be born within its territorial limits, but he must also be born subject to its jurisdiction - that is, in its power and obedience."). $C f$. Mandoli v. Acheson, 344 U.S. 133, 134 (1952) (person born in the United States to alien parents is a "citizen by birth" and "a citizen of the United States by virtue of our Constitution"), and Hintopoulos v. Shaughnessy, 353 U.S. 72, 73 (1957) (child born in the United States to unlawfully resident aliens "is, of course, an American citizen by birth."). For a different twentieth century statutory definition and a Supreme Court opinion that appears to follow it, see infra note 93.

24 See Dred Scott v. Sandford, 60 U.S. 363, 576 (1856) (Curtis, J., dissenting) ("the Constitution uses the language, 'a natural-born citizen.' It thus assumes that citizenship may be acquired by birth. Undoubtedly, this language . . . was used in reference to that principle of public law, well understood in this country at the time of the adoption of the Constitution, which referred citizenship to the place of birth."); Wong Kim Ark, 169 U.S. at 662-63 (adopting Justice Curtis's opinion) and 707 (Fuller, C.J., dissenting) ("it is this rule, pure and simple, which it is asserted ... governed the meaning of the words 'citizen of the United States' and 'natural-born citizen' used in the Constitution as originally framed and adopted. I submit that no such rule obtained during the period referred to, and that those words bore no such construction ...." "). See also Minor, 88 U.S. at 167 (citizenship "by birth" is natural born citizenship; that which results from Congress 's power to establish a uniform rule of naturalization is "by naturalization"); Elk, 112 U.S. at 101-02 (citizenship "by birth" results from birth within and under the jurisdiction of the United States; it is "art. 2, sect. 1" natural born citizenship; and it is 
does not define the term "natural born," but the Court has long held that as a legal term known at the adoption of the Constitution it takes its meaning from English common law and that "at common law in England . . . the rule with respect to nationality was that of the jus soli [right of soil], - that birth within the limits of the jurisdiction of the Crown . . f fixed nationality . . . "'25 The English rule of "citizenship by birth" applied in the colonies and in the United States even before the adoption of the Constitution. ${ }^{26}$

The Court's precedents are consistent with the Founders' understanding. Thomas Jefferson noted in 1783 that the foreign-born child of a natural subject was an alien at common law. ${ }^{27}$ John Adams described "the natural subjects, born within the realm" in $1773,{ }^{28}$ and Alexander Hamilton distinguished foreigners from "the natural subject, the man born amongst us" in $1787 .{ }^{29}$

distinct from "art. 1, sect. 8" naturalized citizenship); and Perkins v. Elg, 307 U.S. 325 (1939) at 333 (distinguishing citizenship "by birth" from citizenship "by parentage"), 330 and 339 (child born in the United States receives "natural" U.S. citizenship "by birth" with presidential eligibility, but "acquired" German nationality later through his father) (quoting with approval an opinion of Attorney General Pierrepont), and 350 (affirming decree declaring a person born within and under the jurisdiction of the United States "to be a natural born citizen of the United States" and extending the decree to bind the Secretary of State). Cf. Kwock Jan Fat v. White, 253 U.S. 454, 464 (1920) (issuing writ of habeas corpus to free appellant despite evidentiary issues regarding his claimed birth in the United States because "[i]t is better that many Chinese immigrants should be improperly admitted than that one natural born citizen of the United States should be permanently excluded from his country."); Perkins v. Elg, 99 F.2d 408, 410, 414 (D.C. Cir. 1938) (following Justice Curtis's Dred Scott dissent and the common law to declare a child born in the United States and subject to its jurisdiction to be a natural born citizen), aff' $d$, 307 U.S. 325 (1939); and Lynch v. Clarke, 1 Sandf. Ch. 583, 663 (N.Y. Ch. 1844) (finding a child to be a citizen under the Constitution because of her birth in New York to sojourning alien parents who had removed her from the United States during her infancy: "I can entertain no doubt, but that by the law of the United States, every person born within the dominions and allegiance of the United States ... is a natural born citizen."). See infra note 33 regarding the Lynch court's view of birth abroad.

25 See, e.g., Minor, 88 U.S. at 167-68 (common law provides definition), Wong Kim Ark, 169 U.S. at 654 (same), and Weedin v. Chin Bow, 274 U.S. 657, 660 (1927) (quoted common law definition). See also John Adams equating "natural born Citizens of the United States" with "natural born subjects of Great Britain" in Letter from John Adams to Thomas Jefferson, National Archives (July 24, 1785), http://founders.archives.gov/ documents/Jefferson/01-08-02-0249; McManamon, supra note 6, at 320-21 (English natural born subject) and 330 ("citizen" for "subject" and equivalence of natural born citizen and natural born subject); and Elhauge, supra note 6, at 12.

26 See, e.g., Wong Kim Ark, 169 U.S. at 659 (English rule of "citizenship by birth" under colonial law, citing Inglis); Inglis, 28 U.S. at 126 (Thompson, J.) (applying the common law rule to birth during the Revolutionary War) and 156, 164 (Story, J., dissenting on other grounds) (same); and Murray v. The Schooner Charming Betsy, 6 U.S. 64, 119-20 (1804) (person born in Connecticut before the Revolution who moved abroad after Independence is a United States citizen absent expatriating event).

27 Jefferson, supra note 1.

28 John Adams, VII. To the Boston Gazette, National Archives (Feb. 15, 1773), http:// founders.archives.gov/documents/Adams/06-01-02-0096-0008.

298 Alexander Hamilton, The Works of Alexander Hamilton 20 (1904), https://archive. org/details/worksalexanderh29hamigoog. 


\section{Citizenship "By Naturalization"}

Any acquisition of citizenship other than by birth in the United States is by naturalization..$^{30}$ A person born outside of the United States to an American parent "is an alien as far as the Constitution is concerned, and 'can only become a citizen by being naturalized ...." ".31 The Constitution grants Congress only limited powers, and the power to grant citizenship to those born outside of the United States is limited to naturalization. ${ }^{32}$ As a result, any statute granting citizenship is a naturalization statute whether it grants citizenship at birth or afterward and regardless of parental nationality. ${ }^{33}$ Consequently a person born to American parents abroad must satisfy a statute to acquire citizenship like other aliens, ${ }^{34}$ because naturalization applies only to aliens. ${ }^{35}$ Although some refer to parents transmitting citizenship to their children under the Roman and continental right of blood (jus sanguinis), citizenship does not descend from parent to child " "either by the common law, or under the common naturalization acts. It is incident to birth in the country, or it is given personally by statute." "36 Foreign-born persons do not receive citizenship from their parents but

$30 \quad$ See, e.g., United States v. Wong Kim Ark, 169 U.S. 649, 702-03 (1898) and Rogers v. Bellei, 401 U.S. 815, 841 (1971) (Black, J., dissenting on other grounds).

31 Miller v. Albright, 523 U.S. 420, 453 (1998) (Scalia, J., concurring) (citation omitted). See also 12 Documentary History of the First Federal Congress of the United States of AMERICA 530 (Helen E. Veit et al. eds., 1994) [hereinafter 12 History] (Rep. Sherman) (difference between a citizen and an alien is that a citizen is born in the country).

32 See, e.g., Bellei, 401 U.S. at 830. See also id. at 840 (Black, J., dissenting on other grounds) and James Madison in 4 AnNals of Cong. 1027 (1794) (Constitution only grants Congress the power "to admit aliens."), http://hdl.handle.net/2027/uc1.\$c227002.

33 See, e.g., Bellei, 401 U.S. at 830. The Wong Kim Ark Court explained that all arguments to the contrary are based on two mistakes of law, citing two American decisions as mistaken in claiming that English and British derivative nationality acts declared the common law: Lynch v. Clarke, 1 Sandf. Ch. 583 (1844), and Ludlam v. Ludlam, 26 N.Y. 356 (1860). See United States v. Wong Kim Ark, 169 U.S. 649, 669-70 (1898). For a further analysis of the erroneous interpretations see McManamon, supra note 6, at 347.

34 See, e.g., Bellei, 401 U.S. at 827-28.

35 See, e.g., Giles Jacob, A New Law Dictionary (1729) (unpaginated) (definition of naturalization: "where a Person who is an Alien, is made the King 's natural Subject by Act of Parliament, whereby one is a Subject to all Intents and Purposes, as much as if he were born so") (emphasis in original), http://hdl.handle.net/2027/mdp.35112203544624. Jacob's law dictionary was the most widely used in the early Republic and was in the personal collections of both Jefferson and Adams. See Gary L. McDowell, The Politics of Meaning: Law Dictionaries and the Liberal Tradition of Interpretation, 44 Ам. J. Legal Hist. 257, 260-61 and n.25 (2000). The Elk Court notes that the Fourteenth Amendment requirement of being "subject to the jurisdiction" relates to the time of birth in the case of birth in the United States and the time of naturalization in the case of naturalization in the United States; it asserts that "[p]ersons not thus subject to the jurisdiction of the United States at the time of birth cannot become so afterwards, except by being naturalized . . ." Elk v. Wilkins, 112 U.S. 94, 102 (1884). This might be read to deny that persons receiving citizenship at birth abroad are naturalized citizens. However, the case involved a person born in the United States who did not receive citizenship at birth because he was a Native American and therefore was not born under the jurisdiction of the United States and could only receive citizenship afterward.

36 See Wong Kim Ark, 169 U.S. at 665 (quoting with approval Horace Binney); see also Miller, 523 U.S. at 434 n.11 (1998). 
instead receive it personally from "congressional generosity" under naturalization statutes. ${ }^{37}$

In declaring a person born within and under the jurisdiction of the United States to be a natural born citizen the Elg Court relied on an opinion by Attorney General Pierrepont that considered the case of a child born in the United States who received German citizenship under German law. ${ }^{38}$ The opinion explains:

Nationality is either natural or acquired. The one results from birth, the other from the operation of the laws of kingdoms or states. Nationality by birth in some countries depends upon the place of birth, in others upon the nationality of the parents ... [I]t is clear ... that by virtue of German laws the son acquired German nationality. It is equally clear that the son by birth has American nationality; and hence he has two nationalities, one natural, the other acquired. ${ }^{39}$

In finding that place of birth determines natural citizenship by birth under the Constitution the Elg Court and Pierrepont follow James Madison, who explained in the First Congress "that birth is a criterion of allegiance. Birth, however, derives its force sometimes from place, and sometimes from parentage; but, in general, place is the most certain criterion; it is what applies in the United States; it will, therefore, be unnecessary to investigate any other. "40 In finding that citizenship conferred by positive enactment is not natural, Pierrepont's opinion accords with Supreme Court's distinction in The Charming Betsy between a person who acquires citizenship by being "born in the United States" from one "becoming a citizen according to the established laws of the country. ..." ${ }^{41}$ It is also consistent with the Court's precedents holding that natural born citizenship is "by birth" and that any other mode of acquiring citizenship is "by naturalization."

The Court's rulings are also consistent with the views of the Founders that foreign-born children were aliens at common law and only became subjects by naturalization, ${ }^{42}$ including James Madison's observation that Britain "naturalizes

37 See, e.g., Bellei, 401 U.S. at 835, and Miller, 523 U.S. at 434 n.11.

38 See Perkins v. Elg, 307 U.S. 325, 330 (1939).

39 Steinkauler's Case, 15 Op. Att'y Gen. 15, 16-17 (1875), http://hdl.handle.net/2027/ msu.31293012342410. See also Kennedy v. Mendoza-Martinez, 372 U.S. 144, 147 (1963) ("Mendoza-Martinez ... was born in this country in 1922 and therefore acquired American citizenship by birth. By reason of his parentage, he also, under Mexican law, gained Mexican citizenship, thereby possessing dual nationality.").

40 M. St. Clair Clarke \& David A. Hall, Cases of Contested Elections in Congress From the YeAr 1789 to 1834, InClusive 33 (1834), http://hdl.handle.net/2027/ mdp.39015030483294.

41 See Murray v. The Schooner Charming Betsy, 6 U.S. 64, 120 (1804). See also Elg, 307 U.S. at 331 (rights from birth within the United States "rest on the organic law of the United States") (quoting with approval Sec. Evarts), and Helen Silving, The Twilight Zone of Positive and Natural Law, 43 CAL. L. Rev. 477, 478-79 and 485 n.10 (1955) (organic law is fundamental law and does not rely on legislation). In the United States natural citizenship by birth follows place of birth; the only other mode of acquisition is naturalization by positive law. Under jus sanguinis, by contrast, natural nationality follows parentage and does not depend on positive law. See, e.g., Perkins v. Elg, 99 F.2d 408, 410 (D.C. Cir. 1938), aff'd, 307 U.S. 325 (1939).

42 See, e.g., Jefferson, supra note 1 (stating rules that a foreign-born child of a British natural subject was an alien at common law and that one cannot be a subject born of 
persons born of British parents in Foreign Countries" ${ }^{43}$ The rulings are also consistent with the understanding of the First Congress in enacting the first federal naturalization act (the "Naturalization Act of 1790"). ${ }^{44}$ Congress's purpose in enacting that law was to define "the terms on which foreigners may be admitted to the rights of citizens . . . by a uniform rule of naturalization. "' ${ }^{45}$ In debating the bill the Representatives recognized that foreign-born children of American parents are aliens in need of naturalization to be admitted as citizens. Discussing those children, Rep. Sherman stated that the difference between a citizen and an alien is that "the citizen is born in the country." ${ }^{46}$ No Representative asserted that the children had any right to citizenship. Reps. Burke and Hartley urged that the act include foreign-born children of American parents, ${ }^{47}$ demonstrating that the children required naturalization to be admitted to citizenship. Rep. Livermore suggested only that it "may be useful" to include them, while Reps. Laurance and Sherman stated that doing so could cause many difficulties and inconveniences -- and Rep. White even argued that including them might cause the children themselves great inconvenience. ${ }^{48}$ The risks of dual nationality were well known then as now. ${ }^{49}$

one kingdom who was born under the allegiance of another, citing Calvin's Case, and characterizing English and British derivative nationality acts as naturalizing the foreignborn child) and Jenings, infra note 82. The Founders were well aware of Blackstone, who described the first of the eighteenth century British derivative nationality acts as naturalizing children. See 1 William Blackstone, Commentaries on the Laws of ENGLAND 363 (1st ed. 1765), https://archive.org/details/lawsofenglandc01blacuoft.

43 James Madison, Memorandum on Impressment and Naturalization, National Archives [1813] (emphasis in original), http://founders.archives.gov/documents/Madison/03-0602-0165.

44 An Act to establish an uniform Rule of Naturalization, March 26, 1790, ch. 3, 2 Stat. 103 (repealed 1795).

45 See 1 Annals of Cong. 933 (charge from Pres. Washington to Congress) and 936 (letter from Congress to Pres. Washington: Congress to enact "a uniform rule of naturalization, by which foreigners may be admitted to the rights of citizens") (1834) [hereinafter 1 ANNALs], http://hdl.handle.net/2027/nyp.33433081775128.

4612 History, supra note 31, at 530. Sherman was a lawyer; judge; signer of the Constitution, Articles of Confederation, Declaration of Independence, and the Association of 1774; and according to Patrick Henry "one of the three greatest men at the Constitutional Convention.” U.S. Government, Roger Sherman, https://www.aoc.gov/art/nationalstatuary-hall-collection/roger-sherman.

47 See 1 Annals, supra note 45, at 1121 (Burke) and 1125 (Hartley), and 12 History, supra note 31 , at 529 (Hartley).

4812 History, supra note 31, at 529 (Livermore and White) and 530 (Laurance and Sherman).

49 See, e.g., Blackstone, supra note 42, at 358 ("straights and difficulties, of owing service to two masters"). "Accidental Americans" assert the injustice of nonconsensual citizenship imposed because of birth to a citizen parent abroad. Their self-identification as not-American and their felt injustice support the principle that they are by nature aliens to the United States.

Nothing in my being will make me accept this seeming injustice especially as one of my children also has a developmental disability and would not be allowed to renounce that $*$ deemed acquired US citizenship and all of its consequences*. I maintain my son is Canadian and I want his Canadian government to guarantee that he and others like him have the same rights — *A Canadian is a Canadian is a Canadian*. 
The Representatives proposed widely varying terms for naturalizing the children, including upon moving to the United States and becoming resident, ${ }^{50}$ upon moving to the United States and becoming resident but only if within a limited time,${ }^{51}$ and at birth but expiring upon reaching majority. ${ }^{52}$ By including the foreign-born children in the final act Congress specified the terms for their admission as citizens. Rep. Tucker was the only member of Congress who discussed the constitutional relationship between admission by statute and presidential eligibility in the debates over the bill. He asserted without objection from any other member that the Constitution:

enables congress to dictate the terms of citizenship to foreigners, yet prevents foreigners being admitted to the full exercise of the rights of citizenship ... because it declares that no other than a natural born citizen, or a citizen at the time of the adoption of this constitution, shall be eligible to the office of president..$^{53}$

In Tucker's view citizenship conferred by Congress is not natural born citizenship and does not confer presidential eligibility. Similarly, John Jay had previously stated that a person may become a citizen by birth or admission, ${ }^{54}$ demonstrating his understanding that those who become citizens by admission are not citizens by birth - and it was Jay who proposed the natural born requirement. ${ }^{55}$

\section{FourteENTH AMENDMENT}

The only two methods of obtaining American citizenship are by birth and by naturalization. Consequently the Fourteenth Amendment's definition of citizenship

calgary411, Again, *Can the U.S. deem somebody to be a U.S. citizen or (in the FATCA, FBAR and CBT world) forcibly impose U.S. citizenship on a person born outside the USA?*, The IsaAc Brock Society (Jan. 16, 2016), http://isaacbrocksociety. ca/2016/01/16/again-can-the-u-s-deem-somebody-to-be-a-u-s-citizen-or-in-the-fatcafbar-and-cbt-world-forcibly-impose-u-s-citizenship-on-a-person-born-outside-the-usa/. 6 Documentary History of the First Federal Congress of the United States of America 1519 (Charlene Bangs Bickford \& Helen E. Veit eds., 1986) [hereinafter 6 HistoRY] (text of H.R. 40) and 12 History, supra note 31, at 529 (Rep. Livermore defending proposal). 12 History, supra note 31, at 530 (Rep. Scott).

$I d$. at 529 (Rep. White).

53 Id. at 154. M. Anderson Berry's detailed analysis of eighteenth century American usage of "foreigners" demonstrates that the Founders would have considered the children to be foreigners even if Rep. Sherman had not described them as aliens. See M. Anderson Berry, Whether Foreigner or Alien: A New Look at the Original Language of the Alien Tort Statute, 27 Berkeley J. INT 'L L. 316, 343 (2009). The Lloyd transcription of Tucker's statement is identical to the quotation above. 3 Thomas Lloyd, The Congressional Register; Or, History of the Proceedings and Debates of the First House of Representatives of the United States of America 218 (1790), http://hdl.handle.net/2027/nyp.33433081774055. The Gales transcription is slightly different and could be read to say merely that the Constitution enables Congress to prevent foreigners from becoming president. 1 ANNALS, supra note 45, at 1116.

54 Jay, supra note 22.

55 See, e.g., McManamon, supra note 6, at 328-29 (history and result of Jay's suggestion). 
is comprehensive and declaratory of original constitutional law. ${ }^{56}$ The common law rule was articulated in the 1608 English decision in Calvin's Case, which Thomas Jefferson relied on in his Notes on British and American Alienage. That case provided "the basis of the American common-law rule of birthright citizenship" that the Fourteenth Amendment merely codified. ${ }^{57}$

\section{E. ROGERS V. BELLEI}

Rogers v. Bellei is an instructive example of the Court's precedents. Aldo Mario Bellei was born in Italy to an American mother and an alien father. The applicable naturalization statute granted him citizenship at birth subject to a condition subsequent requiring five years of continuous physical presence in the United States between the ages of fourteen and twenty eight. Bellei was a citizen at birth under the statute and traveled internationally on a U.S. passport. ${ }^{58}$ However, he failed to meet the five year presence requirement, and the United States revoked his citizenship. Bellei challenged the revocation.

The Court held unanimously that Bellei had no constitutional right to citizenship and could be a citizen, if at all, only by complying with a naturalization statute. The majority stated that the Constitution's definition of citizenship "obviously [does] not apply to any acquisition of citizenship by being born abroad of an American parent. "59 The Justices who dissented on other grounds agreed, with Justice Black explaining that "naturalization when used in its constitutional sense is a generic term describing and including within its meaning all those modes of acquiring American citizenship other than birth in this country." ${ }^{60} \mathrm{He}$ acknowledged the considerable constitutional history of the definition while recognizing that it differs from popular usage. ${ }^{61}$

The majority then held that Bellei had to comply with all of the requirements of the naturalization statute including the condition subsequent. ${ }^{62}$ Because he had

56 See, e.g., Slaughter-House Cases, 83 U.S. 36, 73 (1873) (comprehensive), Minor v. Happersett, 88 U.S. 162, 165, 170 (1875) (declaratory as to child of citizen parents), United States v. Wong Kim Ark, 169 U.S. 649, 676 (1898) (declaratory as to child of alien parents), and McKay v. Campbell, 16 F. Cas. 161, 165 (D. Ore. 1871) (declaratory). Cf. Kawakita v. United States, 343 U.S. 717, 720 (1952) ("Petitioner was born in this country in 1921 of Japanese parents who were citizens of Japan. He was thus a citizen of the United States by birth (Amendment XIV, $\S 1$ ) and, by reason of Japanese law, a national of Japan. ”), and Sugarman v. Dougall, 413 U.S. 634, 652 (1973) (Rehnquist, J., dissenting on other grounds) (Fourteenth Amendment is "by birth or naturalization"). See also Einer Elhauge, The Meaning of the Natural Born Citizen Clause, Originalism BLOG (March 28, 2016) (Fourteenth Amendment "distinguishes citizenship by birth in the U.S. from citizenship by naturalization” citing Wong Kim Ark), http://originalismblog. typepad.com/the-originalism-blog/2016/03/the-meaning-of-the-natural-born-citizenclauseeiner-elhauge.html. But see infra note 146 (regarding comprehensiveness).

57 See Price, supra note 1, at 74, 138-40. See also 12 History, supra note 31, at 530 (Rep. Smith: child born in the United States is a citizen when born even if father is a foreigner).

58 See Rogers v. Bellei, 401 U.S. 815, 817, 819 (1971).

59 Id. at 830.

60 Id. at 841 (Black, J., dissenting on other grounds). See also id. at 845 (Brennan, J., dissenting on other grounds).

$61 \quad I d$. at 840 (Black, J., dissenting on other grounds).

62 Id. at 830. 
no constitutional right to citizenship it did not matter whether Congress granted citizenship at birth subject to a condition subsequent or instead provided citizenship later after meeting a condition precedent. "The proper emphasis is on what the statute permits him to gain from the possible starting point of noncitizenship, not on what he claims to lose from the possible starting point of full citizenship to which he has no constitutional right in the first place." 63

Bellei is controlling precedent demonstrating that derivative citizens are not natural born. The Constitution forbids the nonconsensual revocation of natural born citizenship. ${ }^{64}$ Yet the Court upheld the nonconsensual revocation of Bellei's derivative citizenship. Therefore derivative citizens are not natural born.

\section{Objections And Alternative Theories}

Some assert that derivative citizens like Sen. Cruz are natural born despite contrary Supreme Court precedent and centuries of recognition that a person cannot be a subject born of one sovereign who was born under the allegiance of another. Some object to the common law rule generally, and others assert one of three alternative theories defining natural born citizenship.

\section{A. Alleged Opacity and Ambiguity of the Term "Natural Born Citizen"}

Some argue that the term "natural born citizen" is an opaque and dangerously ambiguous enigma because the Constitution does not define it, the Founders never explained its meaning or their reason for including it in presidential qualifications, and federal courts have not considered it, leaving open questions such as whether a person born abroad on a U.S. military facility or to a serving member of the armed forces is eligible to the presidency. ${ }^{65}$ These arguments are unpersuasive. The

63 Id. at 836. The Bellei majority upheld the condition subsequent on the grounds that the original Constitution and the Fourteenth Amendment only protect persons born or naturalized in the United States and that Bellei was naturalized outside the United States. Id. at 827.

64 See Hall v. Florida, 572 U.S. slip op. 6 (2014) ("No natural-born citizen may be denaturalized."). The Bellei majority found that the original Constitution recognizes only two types of constitutional citizenship: that by birth within and under the jurisdiction of the United States and that by naturalization within and under the jurisdiction of the United States. See Bellei, 401 U.S. at 829-30 (citing Justice Gray's opinion in Wong Kim Ark). Because those naturalized outside of the United States are not constitutional citizens, they cannot be natural born citizens within the meaning of U.S. Const. art. II, § 1, cl. 5. $C f$. Afroyim v. Rusk, 387 U.S. 253, 257 (1967) (striking down a condition subsequent for naturalization within the United States because the Fourteenth Amendment does not permit Congress any "power, express or implied, to take away an American citizen's citizenship without his assent.").

65 See, e.g., Charles Gordon, Who Can Be President of the United States: the Unresolved Enigma, 28 MD. L. Rev. 1, 17-18 (1968); Sarah Helene Duggin \& Mary Beth Collins, Natural Born in the U.S.A.: The Striking Unfairness and Dangerous Ambiguity of the Constitution's Presidential Qualifications Clause and Why We Need to Fix It, 85 B.U. L. 
constitutional definition is simply the common law rule codified in the Fourteenth Amendment to bury forever the Court's decision in Dred Scott. ${ }^{66}$ Federal courts have long adjudicated claims to birthright constitutional citizenship under this standard, including claims based on birth on a U.S. military installation abroad ${ }^{67}$ The Fourteenth Amendment is not an enigma but rather a fundamental part of American constitutional law. No one asserts that it requires reinterpretation except those who seek to apply Roman law and continental legal theories to deny birthright citizenship to minorities born within and under the jurisdiction of the United States. ${ }^{68}$ Any ambiguity in the common law rule is ambiguity about birthright constitutional citizenship, which courts continue to clarify when adjudicating general claims to such citizenship. ${ }^{69}$

Moreover, the Founders were well aware of Calvin's Case and the common law rule. ${ }^{70}$ They relied on Calvin's Case as the judicial and natural law basis of colonial independence from Parliamentary authority. ${ }^{71}$ They had no need to discuss, justify or

Rev. 53, 55 (2005); Lawrence Friedman, An Idea Whose Time Has Come - The Curious History, Uncertain Effect, and Need for Amendment of the "Natural Born Citizen" Requirement for the Presidency, 52 ST. LouIs U. L.J. 137, 139-40 (2008); and Michael Dobbs, McCain's Birth Abroad Stirs Legal Debate, Washington Post (May 2, 2008).

66 See, e.g., United States v. Wong Kim Ark, 169 U.S. 649, 662, 675-76 and 689-90 (1898).

67 See, e.g., Perkins v. Elg, 307 U.S. 325, 350 (1939) (declaring a person to be a natural born citizen of the United States and directing the federal government to treat her as such); Inglis v. Trustees of Sailor's Snug Harbor, 28 U.S. 99, 126 (1830) (Thompson, J.) (application of the common law rule after the Declaration of Independence); and United States ex rel. Guest v. Perkins, 17 F. Supp. 177 (D. D.C. 1936) (denying claim of natural born citizenship from birth to citizen parent abroad). Both Courts of Appeals that have considered the issue of birth abroad on a military facility have denied constitutional citizenship on the ground that such facilities are not within the United States. See Williams v. Attorney General, 458 Fed. Appx. 148 (3d Cir. 2012) (per curiam) (child's claim to derivative citizenship based on asserted maternal birthright citizenship from birth at Guantanamo Bay), and Thomas v. Lynch, 796 F.3d 535 (5th Cir. 2015), cert. denied, 136 S. Ct. 2506 (2016) (birth on a U.S. military facility abroad to a citizen serving in the U.S. armed forces who did not satisfy a statutory parental physical presence requirement). The Thomas decision also precludes the claim that birth abroad to a citizen serving in the armed forces confers natural born citizenship, although the court did not directly address the issue. The implicit holding is consistent with the English common law rule. See, e.g., De Geer v. Stone (1883) 22 Ch. D. 243, 253-54 (military service), https://hdl.handle.net/2027/iau.31858012344986, and LAURIE Fransman, Fransman's British Nationality Law 132, 134 (3d ed. 2011) (birth abroad to a parent in crown service, other than an ambassador, did not confer subject status under the common law, although practice differed).

68 See, e.g., Publius-Huldah, Natural Born Citizen and Naturalized Citizen Explained (Feb. 11, 2016) (citing de Vattel for proposition that natural born citizens are only those born of citizen parents and that '[u]nder some peoples' misreadings of Sec. 1 of the 14th Amendment, illegal alien muslims could come here and drop a baby and the baby could later be President! Our Framers didn't want that!'), https://publiushuldah.wordpress. $\mathrm{com} /$ category/vattel/.

69 See, e.g., Tuaua v. United States, 788 F. 3d 300 (D.C. Cir. 2015) (no birthright constitutional citizenship from birth in American Samoa), cert. denied, 136 S.Ct. 2461 (2016).

70 See, e.g., supra note 42.

71 See, e.g., Alexander Hamilton, The Farmer Refuted, \&c., National Archives ([Feb. 23], 1775), http://founders.archives.gov/documents/Hamilton/01-01-02-0057, and John 
define the qualification because they had considered restricting lesser federal offices to those who were natural born well before drafting the Constitution ${ }^{72}$ and because they were aware that the term "natural born" and its variants were commonly used in the colonies and the early Republic, for example: (a) John Adams describing "the natural subjects, born within the realm" in $1773 ; ;^{73}$ (b) Alexander Hamilton distinguishing foreigners from "the natural subject, the man born amongst us" in 1787:74 (c) John Adams, John Jay and Benjamin Franklin proposing in 1783 to grant British subjects all of the rights "of natural born Citizens" of the United States in exchange for Britain granting U.S. citizens all of the rights of "natural born Subjects" of the crown; ${ }^{75}$ (d) Thomas Jefferson substituting "natural born citizens" for "natural born Subjects" in 1776 draft legislation; ${ }^{76}$ (e) the Founders claiming the rights of natural born subjects in the Declaration and Resolves of the First Continental Congress; ${ }^{.7}$ (f) Massachusetts granting naturalized persons the rights of natural born citizens in $1784-85 ;^{78}(\mathrm{~g})$ slaves petitioning Massachusetts for their liberty and for "all the privileges and immunities of its free and natural born subjects" in 1774; ${ }^{79}$ and (h) state constitutions from 1776 and 1777 progressively granting foreigners the rights of natural born subjects. ${ }^{80}$

The Founders also understood the operation and effects of naturalization. They ensured that naturalized persons were eligible to hold office in the colonies ${ }^{81}$ They understood the international political implications of dual nationality resulting from naturalizing children at birth abroad. ${ }^{82}$ They enacted broad colonial statutes

Adams, VII. To the Inhabitants of the Colony of Massachusetts-Bay, National Archives (Mar. 6, 1775), http://founders.archives.gov/documents/Adams/06-02-02-0072-0008.

72 See the 1781 proposal to restrict the positions of consul and vice-consul to "natural born subjects of the power nominating them" in 21 United States, Journals of the Continental Congress, 1774-1789, at 805 (1912), draft treaty with France, art. I, § 3, https://hdl.handle.net/2027/mdp.39015068547101.

73 Adams, supra note 28.

74 Hamilton, supra note 29, at 20.

75 See John Adams, Draft Articles to Supplement the Preliminary Anglo-American Peace Treaty, National Archives (ca. Apr. 27, 1783) (art. 2 and footnote explanation 2 by The Massachusetts Historical Society), http://founders.archives.gov/documents/Adams/0614-02-0278.

76 See Jefferson's revisions to Edmund Pendleton's Bill for the Naturalization of Foreigners, National Archives (Oct. 14, 1776), https://founders.archives.gov/documents/ Jefferson/01-01-02-0223.

77 Declaration and Resolves of the First Continental Congress, Preamble and Resolutions 2 and 3 (Oct. 14, 1774), http://avalon.law.yale.edu/18th_century/resolves. asp.

783 Acts and Laws of the Commonwealth of Massachusetts 1784-85 (1890-1898), at 125 (ch. 43, 1784) and 508 (ch. 43, 1785), https://hdl.handle.net/2027/iau.31858018606149.

79 Petition, To his Excellency Thomas Gage Governor: - To the Honourable, His Majesty's Council, and The Honourable House of Representatives of the Province of the Massachusetts Bay in General Court assembled; June-Anno Domini 1774, http://www. masshist.org $/$ database $/ 550$ ? mode $=$ transcript.

80 See Pa.Const. $\$ 42$ (1776), and Vt. Const. ch. 2 \XXXVIII (1777).

81 See KettNer, supra note 22, at 77-78 (naturalizations under British law), but see id. at 123-26 (limitations under some colonial naturalizations).

82 For example, Edmund Jenings wrote to John Adams in 1784 describing a British proposal "to Naturalize Children born of English women in foreign parts" and the objection of some members of Parliament that the bill would benefit many children born in the United 
naturalizing immigrants because naturalization operated retroactively, enhancing security to real property and facilitating economic development although also reducing escheats to the crown ${ }^{83}$ leading to Britain revoking the statutes and in part to the grievance in the Declaration of Independence that the king "has endeavoured to prevent the population of these States; for that purpose obstructing the Laws for Naturalization of Foreigners . . . ." 84

In fact it is American derivative citizenship statutes that are opaque, poorly defined and dangerously ambiguous. Interpreting "natural born" to include derivative citizens under a living or responsive constitutional theory would only increase the definitional uncertainties and dangers. Derivative citizenship claims are often technically and factually complex, are typically adjudicated by inhospitable and underqualified administrative bodies rather than federal courts, and for certain claimants involve insurmountable burdens of proof, ${ }^{85}$ exemplified by a judge in 2011 demanding documentary evidence like utility bills or co-worker affidavits to prove residence between 1921 and 1959 of a deceased Mexican American citizen father who had been a seasonal farm worker in the Bracero Program. ${ }^{86}$ Derivative citizenship statutes rely on terms like marriage, legitimacy, custody, and permanent residency that are often undefined by statute or take their meaning from foreign law. They change frequently and lead to continuing litigation and outcomes that differ depending on the child's place of birth and on the ability of American courts and administrators to understand and apply both domestic and foreign law, exemplified by the dispute over whether the 1937 statute granting Sen. John McCain citizenship from his 1936 birth in the Panama Canal Zone was retroactive or merely declaratory of prior law, and by federal officials repeatedly citing a nonexistent provision in the Mexican constitution to deny citizenship to children born in Mexico to American fathers. ${ }^{87}$

States and might be better withdrawn until negotiations with the United States could achieve something for Britain in exchange. See Letter from Edmund Jenings to John Adams, National Archives (Feb. 24, 1784), http://founders.archives.gov/documents/ Adams/06-16-02-0036, and "Bill for declaring the Children of British Mothers naturalborn Subjects, though born Abroad" in 39 The Journals of the House of Commons 870 (reprint 1803) (emphasis in original) [hereinafter JouRNALs], https://books.google.com/ books?id=0hhDAAAAcAAJ. Note that Jenings characterized declaring the children to be natural born as naturalizing them.

83 KetTnER, supra note 22, at 33, 117-21. For the extent of retroactivity, see, e.g., Collingwood v. Pace (1661) 124 Eng. Rep. 661, 686-88 (Bridgman, C.J.), http://hdl. handle.net/2027/inu.30000029143645, and Collingwood v. Pace, 86 Eng. Rep. 262, 271 (argument of Lord Hale), http://hdl.handle.net/2027/coo.31924064794096.

84 The Declaration of IndePendence para. 2 (U.S. 1776). See also Kettner, supra note 22, at 105, 121 (colonial naturalization provisions, revocation, and grievance).

85 See, e.g., Medina, supra note 8, at 407, $417 \mathrm{ff}$.

86 See id. at 433-34 (analyzing Vega-Alvarado v. Holder, 2011 U.S. Dist. LEXIS 9218 (C.D. Cal. 2011), petition for review denied, No. 08-73551 (9th Cir. 2012)). Contrast Leonard v. Grant, 5 F. Cas. 11, 17-18 (D. Ore. 1880) (waiving proof of residence for naturalization of alien white women by marriage to American husbands "notwithstanding the letter of the statute" because years later, when controversy might arise, the proof "may be lost or difficult to find" rendering the naturalization provision "practically nugatory, if not a delusion and a snare.").

87 See, e.g., Gabriel J. Chin, Why Senator John McCain Cannot Be President: Eleven Months and a Hundred Yards Short of Citizenship, 107 Mich. L. Rev. First Impressions 
Their opacity is nothing new. Congress enacted the original federal derivative citizenship provision despite a disagreement over its clarity, ${ }^{88}$ and its scope remains controversial today. ${ }^{89}$ A leading State Department advisor acknowledged in 1934 that "[i]t seems to have been the rule, rather than the exception, that nationality laws fail to state in plain, unmistakable terms what is intended." 90

\section{B. Three Alternative Theories}

\section{Substantive theory}

The first alternative theory claims that the Constitution grants citizenship by descent because eighteenth century British derivative nationality statutes declared or changed the English common law and therefore control the common law definition of "natural born" that the Constitution incorporates. This theory necessarily includes the corollary claims that American derivative citizenship statutes are declaratory of the same British law, not naturalization statutes, and that the Fourteenth Amendment does not provide the comprehensive definition of American citizenship - the amendment leaves open the possibility of jus sanguinis as a third type of constitutional citizenship that is not naturalization. Charles Gordon propounded this theory in an influential 1968 article. ${ }^{91} \mathrm{He}$ admitted that his conclusion was "clouded by elements of doubt" and stated it in highly qualified terms, ${ }^{92}$ and with good reason. The Supreme Court had already rejected all three claims. ${ }^{93}$ In Weedin v. Chin Bow, for example, the Court considered the derivative

1 (2008) (retroactive, citing the statute's text and legislative history and the public advice of a leading State Department advisor), Stephen E. Sachs, Why John McCain Was a Citizen at Birth, 107 Mich. L. Rev. First ImPRESSIONS 49 (2008) (declaratory of prior statutory law, citing Middle English legal drafting conventions and the texts and legislative histories of prior statutes), and Collins, supra note 8, at 2221-22 (Mexican provision).

88 See 12 History, supra note 31, at 529 (Reps. Burke and Livermore) and Michael D. Ramsey, A Reply to Saul Cornell on Natural Born Citizens (part 2), Originalism Blog (Sept. 15, 2016), http://originalismblog.typepad.com/the-originalism-blog/2016/09/areply-to-saul-cornell-on-natural-born-citizens-part-2michael-ramsey.html.

${ }^{89}$ See, e.g., W. Gardner Selby, Ted Cruz says it's always been that babies born to U.S. citizens abroad are citizens from birth, Politifact TeXas (Sept. 4, 2015), http://www. politifact.com/texas/statements/2015/sep/04/ted-cruz/ted-cruz-says-its-always-beenlaw-babies-born-us-c/.

90 Richard W. Flournoy, Proposed Codification of Our Chaotic Nationality Laws, 20 A.B.A. J. 780, 781 (1934).

91 See Gordon, supra note 65, at 13, 18 (the eighteenth century acts changed the common law or were part of the corpus of common law), 9 and n.69 (there is an equally valid argument that the first federal naturalization act was declaratory), 13 and 17 (there is no evidence that the Fourteenth Amendment is exclusive; Congress believes that jus sanguinis rather than naturalization confers citizenship abroad).

$92 \quad I d$. at 32.

93 See, e.g., Slaughter-House Cases, 83 U.S. 36, 73 (1873) (Fourteenth Amendment comprehensive) and Weedin v. Chin Bow, 274 U.S. 657, 665 (1927) (stating common law rule and characterizing American derivative citizenship statute as a naturalization 
citizenship claim of a child born abroad to a citizen father who had also been born abroad. The Court stated the English and American common law rule, which did not apply to Chin because:

at common law in England and the United States, the rule with respect to nationality was that of the jus soli [right of soil], - that birth within the limits of the jurisdiction of the Crown, and of the United States, as the successor of the Crown, fixed nationality, and that there could be no change in this rule of law except by statute ... ${ }^{94}$

The Court acknowledged that Chin met the terms of a British statute but rejected his claim for failure to meet the more restrictive terms of the American naturalization statute, which included a paternal residency requirement:

Congress must have thought that the questions of naturalization and of the conferring of citizenship on sons of American citizens born abroad were related.

Congress had before it the Act of George III of 1773, which conferred British nationality not only on the children but also on the grandchildren

statute by reference to a British derivative nationality act). Even the first U.S. derivative citizenship provision differed significantly from British law and cannot be interpreted to declare the same law. For example, the U.S. act naturalized foreign-born children of naturalized citizens, but with one late and narrow exception the British derivative nationality acts did not naturalize foreign-born children of naturalized subjects. See, e.g., Sasportas v. De la Motta, 10 Rich. Eq. 38, 48 (S.C. Ct. App. 1858) (interpreting language reenacted from the original U.S. provision), https://hdl.handle.net/2027/ mdp.35112102521376; Horace Binney, The Alienigenae of the United States Under the Present Naturalization Laws 21 (1853) (same), http://hdl.handle.net/2027/ mdp.35112102633445; and infra notes 110 and 123 (British acts). Gordon also relies without justification on a twentieth century statutory definition of "naturalization" as the conferring of citizenship after birth. See Gordon, supra note 65, at 15-16. Congress adopted the narrower statutory definition even while recognizing that it differed from the Supreme Court's constitutional definition. See the Nationality Act of 1940, § 101(c), ch. 876, 54 Stat. 1137, and House Committee Print, 76th Cong. 1st Sess., 1 Nationality Laws of the United States: Message from the President of the United States 3-4 (1939) (citing Minor and Wong Kim Ark for the Supreme Court's definition), http://hdl.handle. net $/ 2027 / \mathrm{mdp} .39015059519226$. Section 401 of the Nationality Act of 1940 refers to citizenship "by birth or naturalization" rather than at birth or afterward. Because the act defines naturalization as occurring only after birth, it appears to use citizenship "by birth" to mean citizenship "at birth." Justice Stevens appears to follow this usage in his Miller opinion. See Miller v. Albright, 523 U.S. 424, 435 (1998). Twentieth century usage cannot, however, alter the constitutional definition of "naturalization" or of citizenship "by birth." The statutory definition of "naturalization" is also broader than the constitutional definition because the former includes the post-natal grant of non-citizenship nationality. See, e.g., Rose Cuison Villazor, American Nationals and Interstitial Citizenship, 85 FoRdHAM L. Rev. 1673 (2017) (non-citizenship nationality differs significantly from both citizenship and alienage and was created in the early twentieth century and codified in the Nationality Act of 1940 as a racially exclusionary tool to avoid granting citizenship to residents of territories acquired from Spain in 1898). 
of British-born citizens who were born abroad. Congress was not willing to make so liberal a provision..$^{95}$

The Court's conclusions are consistent with its subsequent decisions in Bellei, Miller, Nguyen v. INS, ${ }^{96}$ and Flores-Villar v. United States.$^{97}$ If the substantive theory were correct then only a constitutional amendment could deny the right to derivative citizenship..$^{98}$ This is flatly inconsistent with Supreme Court decisions upholding narrower derivative citizenship statutes.

Gordon reached his conclusion by reasoning that long-settled British practice reaffirmed in eighteenth century British nationality acts "grant[ed] full status of natural-born subjects to the children born overseas to British subjects." mischaracterizes British law. The nationality acts did not reflect settled British practice, did not apply to foreign-born children of all British subjects, and did not confer the status of a natural born subject.

The common law forbade aliens to inherit real property in order to protect the wealth and security of the realm. ${ }^{100}$ Foreign-born children were aliens, even if born to English parents, so the common law rule excluded children "of many noble and virtuous families from the service of the state, and impoverished the children of opulent parents," and therefore Parliament enacted the "remedial and enlarging"

95 Id. at 665 (recognizing that only the person born in Britain is "British-born"). The Court's statutory reference is to The British Nationality Act, 1772, 13 Geo. 3 c. 21, http://hdl.handle.net/2027/njp.32101013154933. Dating conventions vary for older acts of Parliament. This article titles and dates the British derivative nationality statutes enacted under Anne, George II, and George III in accordance with the Short Titles Act, $1896,59 \& 60$ Vict. c. 14 .

96533 U.S. 53 (2001) (child born abroad to an American father and an alien mother, abandoned by his mother and raised by his father in the United States from age 6, denied citizenship because his father did not meet statutory requirement for acknowledging paternity under oath by child's $18^{\text {th }}$ birthday).

97564 U.S. (2011) (aff'g by an equally divided Court United States v. Flores-Villar, 536 F.3d 990 (9th Cir. 2008)) (child born abroad to an American father and an alien mother denied citizenship because his father did not and could not meet statutory U.S. physical presence requirement).

98 See, e.g., Alexander Porter Morse, Natural-Born Citizen, 31 WASH. L. ReP. 823, 823 (1903) (constitutional right that Congress cannot impair or deny "even if legislation to that end was enacted.”), and William T. Han, Beyond Presidential Eligibility: The Natural Born Citizen Clause as a Source of Birthright Citizenship, 58 DraKe L. REV. 457, 465 (2010) (first generation born abroad has "birthright citizenship that Congress has no power to diminish.”). James Otis provides the nearest support from a Founder for the substantive theory. Otis cited Calvin's Case for the common law rule that one cannot be a subject born of one king who was born under the allegiance of another and described the nationality acts of Parliament from Edward III onward as naturalization acts; however, he also referred to some acts of Parliament, perhaps including the naturalization acts, as declaratory or amendatory of common law and asserted that "[t]he common law is received and practiced upon here ... and all antient and modern acts of parliament that can be considered as part of, or in amendment of the common law ... .” James Otis, The Rights of the British Colonies Asserted and Proved 71 (1764), http://hdl.handle.net/2027/aeu.ark:/13960/t08w4h35q.

99 Gordon, supra note 65, at 7-8 (footnote omitted).

100 See, e.g., Calvin's Case (1608) 7 Co. Rep. 1a, $18 \mathrm{~b}$. 
act De natis ultra mare (Of birth beyond sea) in 1350 (the "Act of Edw. III"). ${ }^{101}$ That act prospectively granted inheritance rights to foreign-born children "whose fathers and mothers" were at the faith and ligeance of the king on the condition "that the mothers of such children do pass the sea by the licence and wills of their husbands." 102 Some authorities interpreted the act more restrictively to exclude children of English parents who had gone abroad without the king's license $\mathrm{e}^{103}$ and others more liberally, both to naturalize the children and to apply to children of an English father and an alien mother under the maxim that a wife is sub potestate viri (under the governance of the husband). ${ }^{104}$ The authorities interpreting the Act of Edw. III depart so far from its terms and are so inconsistent that an AttorneyGeneral for England and Wales remarked in 1763 "that there never was a statute of so doubtful a construction." 105 Courts ultimately read the act in pari materia with the first eighteenth century general derivative nationality acts, ${ }^{106}$ and it did not have any subsequent meaningful effect.

The first eighteenth century general derivative nationality acts were clause 3 of The Foreign Protestants Naturalization Act, 1708 (the "Act of Ann."), ${ }^{107}$ as explained by The British Nationality Act, 1730 (the "Act of Geo. II"). ${ }^{108}$ These acts naturalized the immediate issue of a married British father who was at the time of the child's birth a natural born subject untainted by specified acts of treason, felony or enemy service. ${ }^{109}$ Consequently, all foreign-born children of naturalized British fathers remained aliens - including all foreign-born children of fathers whom the Acts of Ann. and Geo. II had naturalized. ${ }^{110}$ In addition, all foreign-born children

101 Francis Plowden, An Investigation of the Native Rights of British Subjects 41-42 (1784), https://archive.org/details/investigationofn00plowuoft, citing 25 Edw. 3 stat. 2 (1350), http://hdl.handle.net/2027/mdp.39015065181839. Foreign-born children of English parents could not inherit despite their English blood because they lacked allegiance. See, e.g., Godfrey v. Dixon, Cro. Jac. 539 ("true it is there was a disability, but not in the blood, viz. his blood was not the cause of his disability, but the place of his birth; for the law respects not the blood, where there is not any allegiance ..."), http:// hdl.handle.net/2027/nyp.33433009486642.

10225 Edw. 3 stat. 2, cl. 5.

103 See, e.g., Hyde v. Hill (1582) 78 Eng. Rep. 270, http://hdl.handle.net/2027/ inu.30000029143124.

104 See, e.g., Doe dem. Duroure v. Jones (1791) 4 T.R. 300, 308 (Kenyon, C.J.) (Act of Edw. III granted all of the rights of natural born subjects) and 311 (Grose, J.) (maxim), http:// hdl.handle.net/2027/njp.32101066467810. Whether Parliament believed that husbands governed wives is doubtful given the statutory exclusion of children born to women who traveled abroad without their husbands' license. Whether the Act of Edw. III naturalized children instead of merely granting them inheritance rights is an issue of recurring controversy. See, e.g., McManamon, supra note 6, at 324-25 and 339-40.

105 Leslies v. Grant (1763) 2 Pat. 68, 74 n.1, http://hdl.handle.net/2027/ umn.31951d019522610.

106 See, e.g., Duroure, 4 T.R. at 308-09 (Kenyon, C. J.) and 311 (Grose, J.).

1077 Ann. c. 5, http://hdl.handle.net/2027/mdp.39015065182050.

1084 Geo. 2 c. 21, http://hdl.handle.net/2027/mdp.39015035134082.

109 See 7 Ann. c. 5, cl. 3, and 4 Geo. 2 c. 21, cls. 1 \& 2. See also Fransman, supra note 67, at 132, and Shedden v. Patrick (1854) 149 Rev. Rep. 55, 90-91 (a non-marital child is nullius filius and therefore does not have a British father), http://hdl.handle.net/2027/ iau.31858017125307.

110 See, e.g., Fransman, supra note 67, at 132 (Acts of Ann. and Geo. II inapplicable to children of post-natally naturalized subjects and to children of fathers made subjects by 
of British mothers and alien fathers remained aliens, as did all those of tainted natural born British fathers and all foreign-born non-marital children (even if both parents were natural born subjects). The purpose of the acts was to increase the wealth of the British state by encouraging those within the narrow statutory class to move into the realm with their families' foreign wealth by allowing them to inherit real property there. ${ }^{111}$ The Acts of Ann. and Geo. II did not recognize or establish transmission of nationality by right of blood but rather naturalized a narrow group of children for the economic benefit of the state.

The restriction to the immediate issue of natural born fathers was based on the plain meaning of the term "natural born subjects" in the statutes and on the feared consequences of interpreting the term more broadly. The Acts of Ann. and Geo. II naturalized foreign-born children whose fathers were "natural born subjects." Those acts and all other British naturalization acts deemed their beneficiaries to be natural born subjects. Some asserted that naturalization made one a natural born subject so that the Act of Ann. applied to children of naturalized fathers ${ }^{112}$ with the consequence that the act would apply abroad to all posterity. Lord Bacon had claimed that the Act of Edw. III operated the same way on the foreign-born children of English parents with the "strange" consequence that their "descendents are naturalized to all generations: for every generation is still of liege parents, and therefore naturalized: so as you may have whole tribes and lineages of English in foreign countries. " 113 However, courts and Parliament rejected this interpretation.

The earliest apparent judicial decision came when the issue "was put to the whole judges in England" in Leslies v. Grant (1763), ${ }^{114}$ a House of Lords inheritance decision rendered by the most prominent jurists of the time. ${ }^{115}$ Counsel for appellants stated that the case turned on whether the term "natural born subjects" in the Act of

those acts). Similarly, foreign-born children of fathers who were subjects by annexation were aliens at common law. See id. at 132 (noting that it seems that practice differed).

111 See, e.g., 7 Ann. c. 5, Preamble (purpose to increase the wealth and strength of the nation), and Dundas v. Dundas (1839) 12 Scot. Jur. 165, 167 (report of Lord Cuninghame referring the case to the whole court: Acts of Ann. and Geo. II "appear to have been framed purposely to encourage and bring back persons of British extraction, born aliens, to their allegiance, and still to bestow on them their inheritance in this country, if any descended to them. "), http://hdl.handle.net/2027/coo.31924065520599.

112 See, e.g., 1 George Wallace, A System of the Principles of the Law of Scotland 67-68 (1760) (pre-dating the 1763 and 1772 authorities discussed infra notes 120 and 122 and accompanying text).

113 See Calvin's Case (1608) 2 St. Tr. 560, 585 (assuming that no offspring married aliens), http://hdl.handle.net/2027/njp.32101049431156. Chief Justice Bridgman interpreted the Act of Edw. III to the same effect and urged interpreting it strictly to require both parents to be English because otherwise the foreign-born sons of an English father and an alien mother would "be as those born in England, then the sons of those sons should be denizens, and nati natorum, \&c. [for generations to come]; and so the King have more subjects who shall have the privilege of Englishmen, than is fit or safe for the realm." Collingwood v. Pace (1661) 124 Eng. Rep. 661, 675.

1142 Pat. 68, 74. The Attorney-General's argument in the case refers to an opinion of Lord Hailes on point. See id. at 74 n.1. The author cannot find that opinion.

115 The judges included Lord Pratt, Chief Justice of the Court of Common Pleas; Lord Mansfield, Chief Justice of the Court of King's Bench; Lord Hardwicke, former Lord Chancellor and Chief Justice of the Court of King's Bench; and Lord Wilmot, future Chief Justice of the Court of Common Pleas. 
Ann. meant only "persons who were actually born within the king's dominions " and argued that it did not. ${ }^{116}$ The Attorney-General for England and Wales explained to the contrary that the act "restrains naturalization within the father as a natural born subject" and that "[n]atural born subjects are mentioned in the acts of Parliament to be a subject born in England." 117 Counsel for respondents maintained similarly that "the privilege of a natural born subject" that a foreign-born father is entitled to plead under the Acts of Ann. and Geo. II is a "personal privilege . . . confined to him alone, and does not entitle his issue to the same benefit." 118

The judges first considered similar statutes including the Act of Edw. III and found that they applied only to the immediate issue of "a natural born subject, in fact and not by fiction." 119 The court rejected the claim that the term included fathers born outside the realm, stating that "[i]f the Parliament had intended this to be the case, they would have expressed it more clearly in the act." ${ }^{120}$ The judges also reasoned that including children of those fathers would undermine the Act of Settlement, which restricted the rights of naturalized subjects other than those "born of English Parents" and "would let in all sorts of persons into the family rights, Jews, French, \&c., without any test or qualification - without any residence" with the result "in terror" that the law "might naturalize one-half of Europe." 121 Persons born abroad and naturalized under acts of Parliament were not in fact natural born subjects. Their foreign-born children were aliens.

Parliament concurred with the Leslies decision in the final statute on which Gordon relies, The British Nationality Act, $1772,{ }^{122}$ (the “Act of Geo. III, ” together with the Acts of Ann. and Geo. II, the "British nationality acts" or the "Acts"). Parliament acknowledged that no prior law applied "farther than to the Children born out of the Ligeance of his Majesty, whose Fathers were natural born Subjects" and by the act extended naturalization one generation farther, to certain foreignborn children of untainted married fathers who were entitled to the privileges of natural born subjects under the derivative nationality clause of the Act of Ann. ${ }^{123}$

Leslies, 2 Pat. at 74 n.1.

Id. (emphasis in original).

Id. at 72 .

Id. at $76-77$.

120 Id.

121 Id. at 77. See also An act for the further limitation of the crown, and better securing the rights and liberties of the subject, $12 \& 13$ Will. 3 c. 2 (1700) (also known as the Act of Settlement) (exemption for children "born of English parents"), http://hdl.handle. net/2027/nyp.33433019370828. The father in Leslies was born prior to the enactment of the Act of Ann. See Leslies, 2 Pat. at 74 n.1. Nevertheless counsel and the court argued and decided the case on the grounds stated above.

12213 Geo. 3 c. 21

123 See id., Preamble and cl. 1 (class of fathers) and Shedden v. Patrick (1854) 149 Rev. Rep. 55, 90-91 (married). Some loosely characterize the Act of Geo. III as conferring British nationality on grandchildren of natural born paternal grandfathers, but this is incorrect; the act only naturalized those whose fathers were entitled to the rights of a natural born subject under the Acts of Ann. and Geo. II and who met the other requirements of the Act of Geo. III. See, e.g., A Question of Nationality, 27 L. J. 447, 448 (1892), https://hdl. handle.net/2027/iau.31858002992240. It did not naturalize the grandchild, for example, if the grandfather had been tainted or unmarried at the time of the father's birth, or if the father was tainted or unmarried at the time of the grandchild's birth. The grandfather did not transmit British nationality by blood through the father to the grandchild. Rather, the 
The purpose of the Act of Geo. III was to entitle the second generation born abroad "to come into this Kingdom, and to bring hither ... their Capital" so that the state would not lose the benefit of their families' foreign wealth. ${ }^{124}$ Because the fathers were not natural born subjects, the Act of Geo. III referred to them in very specific terms:

Fathers [who] were or shall be, by virtue of a Statute made in the Fourth Year of King George the Second, to explain a Clause in an Act made in the Seventh Year of the Reign of Her Majesty Queen Anne, for naturalizing Foreign Protestants, which relates to the natural born Subjects of the Crown of England, or of Great Britain, intitled to all the Rights and Privileges of natural born Subjects of the Crown of England, or of Great Britain .... ${ }^{125}$

Because the fathers were foreign-born Parliament doubted that they were even British for purposes of the parentage exception to the disabilities of the Act of Settlement. ${ }^{126}$ Parliament included a special provision in the Act of Geo. III exempting the children it naturalized from those disabilities. ${ }^{127}$ Addressing the Leslies judges' fears, the act imposed numerous restrictions and qualifications. It did not "repeal, abridge or any ways alter, any Law, Statute, Custom, or Usage . . . concerning Aliens' Duties, Custom or Usage” or grant "any Privilege, Exemption, or Abatement, relating thereto, in favour of any Person naturalized by virtue of" the act unless he moved to the realm, resided there, took and subscribed oaths and a declaration, took the sacrament in the Church of England or another Protestant or reformed church, and filed a witnessed and attested certificate in court. ${ }^{128}$ Even then it did not validate any claim to property that had accrued more than five years before the beneficiary satisfied its conditions. ${ }^{129}$

Consequently the Act of Geo. III discriminated against, among others, Catholic, Jewish, nonresident and nonmarital children. British derivative nationality stopped there. No general law naturalized foreign-born children of any other naturalized father. In particular, no law naturalized the foreign-born child of a father whom the Act of Geo. III had naturalized, even though the child's bloodline traced directly through a father, grandfather, and great-grandfather who were all British subjects. The Act of Geo. III did not recognize or establish transmission of nationality by right of blood but rather naturalized an even narrower group of children than the Acts of Ann. and Geo. II, again for the economic benefit of the state.

Act of Geo. III conferred British nationality personally on the grandchild if its statutory conditions were met.

124 See 13 Geo. 3 c. 21, Preamble.

${ }_{125} I d$. at cl. 1 (emphasis in original).

126 This involved the interpretation of "English" parentage in the Act of Settlement independently from the term "natural born subjects" in the Acts of Ann. and Geo. II. See Great Britain, Report From the Select Committee on the Laws Affecting Aliens: Together With Minutes of Evidence And Index 13 (1843), http://hdl.handle.net/2027/ mdp.35112102556778 [hereinafter Select Committee].

127 See id. and 13 Geo. 3 c. 21, cl. 1.

128 See 13 Geo. 3 c. 21, cl. 3.

129 See id., cl. 4. 
Subsequent judicial decisions applied the Acts of Ann. and Geo. II consistently with the Leslies decision. Judges continued to rule that the term "natural born subject" in those acts meant only persons who were subjects "from nativity within the realm" and not "from statutes, or patents of naturalization," 130 reasoning that the plain meaning of the term was a subject "by birth," not a subject by "any other mode." 131 As Chief Judge Abbott concluded for the King's Bench in Doe dem. Thomas v. Acklam:

A child born out of the allegiance of the Crown of England is not entitled to be deemed a natural born subject, unless the father be, at the time of the birth of the child, not a subject only, but a subject by birth. The two characters of subject and subject by birth, must unite in the father. ${ }^{132}$

Statutes that deemed persons to be natural born for all purposes did not make them natural born subjects "in fact" or "in the common meaning of the term." 133 The statutes merely deemed them to be natural born by a legal fiction. ${ }^{134}$ The Acts of Ann. and Geo. II did not apply to children of naturalized fathers (not even fathers whom those acts had naturalized at birth) because those fathers were "by their birth ... the subjects of another power, and not the subjects of Britain." 135 The courts interpreted the term "natural born subjects" in accordance with its common law meaning. As the leading twenty-first century British treatise states the common law rule, "birth within the Crown's dominions and allegiance . . . conferred British subject status 'by birth' ...."136

130 Dundas, 12 Scot. Jur. at 170 (Jeffrey and Mackenzie, JJ.). See also id. at 171 (Moncreiff, J.) (Acts applied only to children "whose father was truly and actually a natural-born subject") (emphasis in original) (Moncreiff disagreed with the majority decision in the case on other grounds); De Geer, $22 \mathrm{Ch}$. D. at 253 (Act of Ann. only applies to child of great grandfather, the last ancestor who was a natural born subject at common law); and The King v. The Superintendent of Albany Street Police Station, or Ex parte Carlebach [1915] 3 K.B. 716, 722 (Reading, C.J.) (Acts only apply to children whose fathers are in fact natural born subjects and as a result claimant must rely on later statutes), http://hdl. handle.net/2027/inu.30000022559334.

131 See Doe dem. Thomas v. Acklam (1824) 26 Rev. Rep. 544, 556-57, http://hdl.handle. net/2027/pst.000033906621.

132 Id.

133 See, e.g., Carlebach, 3 K.B. at 722 (Reading, C.J.), and Dundas, 12 Scot. Jur. at 171 (Moncreiff, J.). See also Elhauge, supra note 6, at 29.

134 See Dundas, 12 Scot. Jur. at 171 (Moncreiff, J.). See also 1 William Blackstone,Commentaries on the Laws of England 373 (7th ed. 1775) (the Acts only deemed persons to be natural born), https://hdl.handle.net/2027/nyp.33433008579496; infra note 218; and Eric Posner, Ted Cruz Is Not Eligible to Be President, Slate (Feb. 8,2016 ) (treating someone as natural born to all intents and purposes is a legal fiction), http://www.slate.com/articles/news_and_politics/view_from_chicago/2016/02/trump_ is_right_ted_cruz_is_not_eligible_to_be_president.html.

135 Dundas, $12 \overline{\text { Scot. Jur. at }} \overline{7} 1$ (Moncreiff, J.).

136 Fransman, supra note 67, at 130 (emphasis omitted). Some incorrectly characterize citizenship conferred by statute at birth as citizenship "by birth." See, e.g., Michael D. Ramsey, Seth Barrett Tillman on James Bayard on Natural Born Citizens [UPDATED], ORIGINALISM BlOG (April 6, 2016) (quoting James Bayard), http://originalismblog.typepad. com/the-originalism-blog/2016/04/seth-barrett-tillman-on-james-bayard-on-natural- 
Contrary to Gordon's claim, Britain recognized that foreign-born children of British subjects were aliens unless one of the British nationality acts applied to them. ${ }^{137}$ Those acts were interpreted or drafted to minimize the number of naturalized foreign-born children lest too many Europeans become British subjects. They were interpreted or drafted to discriminate against children of almost every class of naturalized subjects; those of Jewish, Catholic, French or other disfavored heritage; children of British mothers and alien fathers; ${ }^{138}$ nonmarital and nonresident children; and children of tainted fathers. Finally, as described below in Part III.C.3, even when the Acts applied they did not always confer the rights of a British subject under international law and may not have imposed any obligations from birth. From their start in 1350 the English and British statutes incorporated exclusions and limitations absent from the common law rule. ${ }^{139}$ For the reasons stated above, the substantive theory cannot provide the doctrinal or historical definition of a natural born citizen.

\section{Procedural theory}

The second theory claims "that the phrase 'natural born Citizen' has a specific meaning: namely, someone who was a U.S. citizen at birth with no need to go

born-citizensmichael-ramsey.html. See also Seth Barrett Tillman, On Ted Cruz's Eligibility for the Presidency, The New Reform Club (Mar. 31, 2016, 9:56 AM), http://reformclub. blogspot.ie/2016/03/on-ted-cruzs-eligibility-for-presidency.html, and Selby, supra note 89 (quoting Sen. Cruz). This is contrary to the constitutional definition of the term as well as the British definition from which it derives. See supra notes 20-21 and 23 (constitutional definition and the distinction between citizenship by birth and by naturalization). The nearest support from a Founder is by George Washington who referred in 1796 to "[c]itizens by birth or choice," perhaps suggesting that naturalization is limited to the post-natal acquisition of citizenship by deliberate choice. See George Washington, Farewell Address, National Archives (Sept. 19, 1796), http://founders.archives. gov/documents/Washington/99-01-02-00963. Cf. V. 1 PT. 2 St. George Tucker, Blackstone's Commentaries: With Notes of Reference, to the Constitution and Laws, of the Federal Government of the United States; And of the Commonwealth of VIRGINIA 101 (1803) (distinguishing "[a]liens by birth" from "aliens by election" under U.S. law and asserting that persons receiving citizenship from birth to citizen parents abroad under congressional statutes are not "[a]liens by birth"), https://hdl.handle. net $/ 2027 / \mathrm{mdp} .35112203968369$.

137 See, e.g., Dundas v. Dundas (1839) 12 Scot. Jur. 165, 169 (Jeffrey and Mackenzie, JJ.) (after American independence "any British subject who ... visited their territory, and had children born among them, must have submitted to have seen those children dealt with as aliens in this country, but for the protection of the Statutes now in question ....”).

138 This was not an unconscious reflection of gender norms but rather a deliberate enforcement of them. Prior statutes naturalized children born abroad during limited periods if either their mother or father was a natural born subject. See 29 Car. 2 c. 6 (1676), and $9 \& 10$ Will. 3 c. 20 (1697-98). In addition, some understood the Act of Ann. to apply if either the mother or the father was a natural born subject before the Act of Geo. II explained it to apply only to children of natural born fathers. See Doe dem. Duroure v. Jones (1791) 4 T.R. 300, 309 (Kenyon, C.J.).

$139 C f$. Craw v. Ramsey (1670) 124 Eng. Rep. 1072, 1075 (children born in the king's dominions could purchase and implead in the realm even if born to unmarried or foreign parents), http://hdl.handle.net/2027/inu.30000029143645. 
through a naturalization proceeding at some later time." ${ }^{140}$ Paul Clement and Neal Katyal make this claim in a Commentary on which Sen. Cruz relies to assert his presidential eligibility. ${ }^{141}$ Under this theory if Congress enacted a statute naturalizing at birth all heirs to the British throne then those heirs would be eligible to the presidency. ${ }^{142}$ Clement and Katyal argue that the Founders intended this meaning and its application to foreign-born children of citizens because British practice "recognized that children born outside of the British Empire to subjects of the Crown were subjects themselves and explicitly used 'natural born' to encompass" them, because Congress has recognized since the Founding that children born to citizens abroad are generally themselves citizens at birth without the need for naturalization, and because the First Congress explicitly recognized that they are natural born citizens in the Naturalization Act of $1790 .{ }^{143}$ Supreme Court precedents, the Constitution's history and structure, and the Naturalization Act of 1790 preclude this interpretation.

\section{a. Supreme Court precedents}

First, the rights and capacities of every naturalized person are the same as those of every other. They are inherent in naturalized American citizenship, which Congress may grant but cannot define or differentiate. The Constitution forbids Congress "to give, to regulate, or to prescribe" those capacities or "to enlarge or abridge those rights. The simple power of the national Legislature, is to prescribe a uniform rule of naturalization, and the exercise of this power exhausts it, so far as respects the individual. " 144 Congress cannot grant more rights to one class of naturalized citizens than to another by specifying different effective dates for their naturalization. ${ }^{145}$ The Court's decisions in Osborn and Schneider reject congressional authority to create hierarchies of citizenship. ${ }^{146}$

140 See Paul Clement \& Neal Katyal, Commentary: On the Meaning of "Natural Born Citizen," 128 Harv. L. Rev. F. 161, 161 (2015). Earlier articulations of this theory include Cyril C. Means, Jr., Is Presidency Barred to Americans Born Abroad?, U.S. News \& World Report 26 (Dec. 23, 1955), and Jill A. Pryor, The Natural-Born Citizen Clause and Presidential Eligibility: An Approach for Resolving Two Hundred Years of Uncertainty, 97 YALE L.J. 881 (1988).

141 See Clement \& Katyal, supra note 140, at 161-62, and Response, supra note 4, at 18.

142 Jill A. Pryor forthrightly acknowledges and defends this consequence of the procedural theory. See Pryor, supra note 140, at 898-99.

143 Clement \& Katyal, supra note 140, at 161-62.

144 Osborn v. Bank of the United States, 22 U.S. 738, 827 (1824). See also Schneider v. Rusk, 377 U.S. 163, 165-66 (1964) (quoting and following Osborn).

$145 C f$. Barthelemy v. Ashcroft, 329 F.3d 1062 (9th Cir. 2003) (same standard of constitutional review applies to derivative citizenship statutes granting automatic citizenship after birth as at birth).

146 See, e.g., Rogers v. Bellei, 401 U.S. 815, 839 (1971) (Black, J., dissenting on other grounds). The Bellei majority took great pains to deny that the condition subsequent created secondclass citizenship for persons naturalized outside of the United States. Bellei, 401 U.S. at 835-36. The majority opinion is consistent with the principle that there are only two ways to obtain American citizenship, by birth and by naturalization. However, by distinguishing two types of naturalized citizenship it could conflict with the longstanding principle that the Fourteenth Amendment is comprehensive. See, e.g., Slaughter-House Cases, 83 U.S. 36, 73 (1873) (Fourteenth Amendment comprehensive), and Bellei, 401 U.S. at 827 ("He simply 
Second, the Court's Bellei decision precludes this theory. Bellei was a citizen at birth without the need to go through a later proceeding, yet the Court upheld the nonconsensual revocation of his citizenship even though no one may denaturalize a natural born citizen. Third, the proposal is inconsistent with the Court's definition of common law citizenship "by birth" in Minor, Elk, Wong Kim Ark, and Elg. Clement and Katyal acknowledge that the term should be interpreted in accordance with the common law but inexplicably cite the Acts of Ann. and Geo. II to characterize the common law. ${ }^{147}$ Their error is surprising because they concede that "for better or worse, a naturalized citizen cannot serve" as president, ${ }^{148}$ and they must have been aware of the constitutional rule that children who acquire citizenship at birth to American parents abroad are naturalized citizens. Katyal asserted the constitutional rule before the Supreme Court as Acting Solicitor General. ${ }^{149}$ The constitutional distinction is between citizenship conferred by birth or by naturalization, not at birth or afterward.

\section{b. Constitutional history and structure}

British law does not support the procedural theory. As discussed above, Britain recognized that foreign-born children of subjects were aliens and naturalized only narrow categories of them for the economic benefit of the British state. In addition, the British nationality acts did not apply strictly to those who became subjects at birth without later proceedings. The Acts of Geo. II and Geo. III were retroactive, deeming persons to be natural born who were alive at enactment and in some cases already dead -- and the Act of Geo. II even retroactively denaturalized some persons covered by the Act of Ann. ${ }^{150}$ The Act of Geo. III did not grant or alter any specified

is not a Fourteenth-Amendment-first-sentence citizen.”) and 843 (Black, J., dissenting) (majority's decision inconsistent with Fourteenth Amendment as comprehensive definition). Cf. United States v. Wong Kim Ark, 169 U.S. 649, 714-15 (1898) (Fuller, C.J., dissenting) (the grant of statutory citizenship at birth abroad is unconstitutional if it is naturalization because the Fourteenth Amendment only applies to those born in or naturalized in the United States). If Bellei is good law on this point, however, it stands for the proposition that persons naturalized at birth outside of the United States have fewer rights - not more - than those who are naturalized within the United States afterward.

147 Clement \& Katyal, supra note 140, at 161-62. Clement and Katyal even describe the two acts as statutes. Id. at 162. See also Elhauge, supra note 6, at 26.

148 Clement \& Katyal, supra note 140, at 164.

149 See, e.g., Elhauge, supra note 6, at 23-24.

150 See 4 Geo. 2 c. 21 , cl. 1 (children of fathers who "were or shall be natural-born subjects"), cl. 2 (children of tainted fathers) and cl. 3 (deceased offspring); 13 Geo. 3 c. 21 , cl. 1 (children of fathers who "were or shall be" entitled to the privileges of a natural born subject under the derivative nationality clause of the Act of Ann.); De Geer v. Stone (1883) 22 Ch. D. 243, 252 (applying the 1708 Act of Ann. to a father born in 1696 and the 1772 Act of Geo. III to his son born in 1744); FrANSMAN, supra note 67, at 133; and PLOWDEN, supra note 101, at 143-44 (criticizing the Act of Geo. II for its retroactive effect). The Act of Ann. applied to "the children of all natural-born subjects," which could be interpreted to require both parents to be natural born (which would make the Act of Geo. II retroactively broader). See 7 Ann. c. 5, cl. 3. Alternatively, it could be interpreted to apply if either parent was (which would make the Act of Geo. II retroactively narrower, denaturalizing children of natural born mothers and alien fathers). See Doe dem. Duroure v. Jones (1791) 4 T.R. 300, 309 (Kenyon, C.J.) (it was supposed that the Act of Ann. applied to children of British mothers prior to the Act of Geo. II). 
privileges or laws applicable to foreign offspring until they completed post-natal proceedings. The fact that the Acts deemed children to be natural born is irrelevant. All British naturalization statutes deemed their beneficiaries to be natural born. The Act of Geo. III, for example, utilized the same language as the act naturalizing persons who resided in the colonies for seven years, with each deeming its beneficiaries to be natural born and each referring to them as "naturalized by virtue of" the act. ${ }^{151}$

Moreover, the British and American statutes provide no support for an expansive definition that includes everyone who is a citizen at birth. The Naturalization Act of 1790 only applied to children of American citizens, and the Acts only applied to the immediate issue of married male natural born subjects and to one further generation born abroad. The broader purported definition would include statutes naturalizing children who lack any source of U.S. allegiance such as ones granting citizenship at birth to every heir to the British throne. There is no historical or doctrinal support for such a broad interpretation of presidential eligibility.

Finally, even if the Constitution gave Congress an implied power to differentiate naturalized citizenship the purported definition would violate constitutional principles of separation and limitation of powers. ${ }^{152}$ The Constitution forbids members of Congress even to be electors in the Electoral College. ${ }^{153}$ It can hardly allow the legislature to define eligibility to the highest office in the executive branch, including unilaterally by overriding a presidential veto. ${ }^{154}$ The purported definition would also unconstitutionally allow Congress to impose presidential qualifications beyond those in the Constitution by including them in the statutory conditions for citizenship at birth. ${ }^{155}$ For example, the Constitution requires only fourteen years of personal residency for eligibility, but derivative citizenship statutes have included requirements of continuous physical presence between particular ages (as in Bellei) and parental residency (as in Chin Bow). One danger of this and similar theories is that they assert greater congressional power over citizenship than constitutional doctrine and history authorize..$^{156}$

15113 Geo. 3 c. 21, cls. 1 and 3, and 13 Geo. 2 c. 7, cls. 2 and 6 (1740). See also Elhauge, supra note 6, at 29-30 (demonstrating similar language).

152 Charles Gordon, who was general counsel of the Immigration and Naturalization Service and author of a twenty volume work on immigration law, considered this theory only a "hypothesis" in 1968 and acknowledged that it raises "the question of whether Congress can enlarge or modify the categories of" citizens eligible to the presidency, yet concluded in qualified terms that it was likely correct. See Gordon, supra note 65, at 9 and 31, and Nick Ravo, Charles Gordon, 93, I.N.S. Counsel, New York Times (May 2, 1999), http://www.nytimes.com/1999/05/02/us/charles-gordon-93-ins-counsel.html. See also McManamon, supra note 6, at 335, and Elhauge, supra note 6, at 35.

153 See U.S. Const. art. II, § 1, cl. 2.

154 See, e.g., The Immigration and Nationality Act of 1952 (The McCarran-Walter Act), Pub. L. 82-414, 66 Stat. 163, which included provisions for citizenship at birth and which Congress enacted by override after Pres. Truman vetoed it because of its discriminatory terms. See Department of State, Office of the Historian, The Immigration and Nationality Act of 1952 (The McCarran-Walter Act), https://history.state.gov/milestones/1945-1952/immigration-act.

155 Qualifications for constitutional offices are limited to those that the Constitution specifies. See, e.g., Powell v. McCormack, 395 U.S. 486, 522 (1969), and U.S. Term Limits, Inc. v. Thornton, 514 U.S. 779 (1995).

156 Countering such theories, Justice Curtis recognized that the only express power the Constitution grants Congress over citizenship is to remove "the disabilities of foreign 


\section{c. The Naturalization Act of 1790}

The Naturalization Act of 1790 contradicts the proposed definition. As explained above, the First Congress recognized that foreign-born children of American citizens are aliens who can only become citizens by naturalization that does not confer presidential eligibility. The act only provided that the children shall be "considered as" natural born citizens. That term does not support an inference that Congress meant a citizen at birth or to confer presidential eligibility. The first draft of the final bill, H.R. 40, provided that "the children of citizens of the United States, that may be born beyond sea, or out of the limits of the United States, shall be considered as natural born citizens, on their coming to reside in the United States. "157 The drafters used the term "considered as natural born" for persons who could not become citizens until after their births. It is unlikely that they intended the term to confer presidential eligibility. That would allow foreign-born persons to live to adulthood entirely abroad without any allegiance to the United States and then after moving to the United States and residing for fourteen years become eligible to the presidency.

Rep. White, who recognized the inconvenience of dual nationality, proposed that the children would "be considered as natural born until they arrive at the age of 22 years." 158 He could not have meant the term to confer presidential eligibility because his proposed citizenship would expire thirteen years before the children reached the minimum age for eligibility. ${ }^{159}$ Another amendment proposed that every alien naturalized under the act's general provision "shall be considered as a natural born Citizen . . . ."160 The drafters of that proposal used the term for persons who could not become citizens until after their births and could not have intended to confer presidential eligibility or the natural born requirement would have been meaningless. ${ }^{161}$ A final proposal would have considered foreign-born minor children as natural born citizens upon the naturalization of their parents. ${ }^{162}$ The drafters of that proposal used the term for persons who could not become citizens until after their births and could not have intended to confer presidential eligibility on those alien-born children of alien-born parents.

birth.” See Dred Scott v. Sandford, 60 U.S. 363, 578 (1856) (Curtis, J., dissenting). For a criticism of theories asserting greater congressional power see McManamon, supra note 6 , at $344-45$.

1576 History, supra note 50, at 1519. Seven of the nine Representatives on the select committee that produced H.R. 40 were lawyers, including Rep. Sherman, supra note 46. See 6 History, supra note 50, at 1515 (appointing among others Reps. Hartley, Jackson, Laurance, Moore, Sedgwick, Seney and Sherman), and United States, Biographical Directory of the United States Congress 1774-2005, at 1210, 1319, 1423, 1608, 1885, 1888, and 1902 (2005).

15812 History, supra note 31, at 529.

159 See U.S. Const. art. II, § 1, cl. 5 (thirty five year minimum).

160 See 1 Documentary History of the First Federal Congress of the United States of America 255 n.22 (Linda Grant de Pauw et al. eds., 1972).

161 Two other proposals would have granted all of the rights and privileges of a natural born citizen to those naturalized under the act's general provision. See 6 History, supra note 50, at 1521 n.4 and n.6. The drafters of those proposals could not have intended to confer the privilege of presidential eligibility either, or again the natural born requirement would have been meaningless.

162 See id. at 1521 n.5. 
Members of the First Congress did not use the phrase "considered as natural born" to mean eligible to the presidency or a citizen at birth. They simply followed the Act of Edw. III to describe the children as born beyond sea and the Acts of Ann., Geo. II, and Geo. III to deem ("consider") them as natural born for purposes of granting them the general rights of naturalized citizens. Indeed, courts read even the final terms of the act to confer post-natal citizenship upon some foreign-born children of American parents until the Supreme Court interpreted the terms more narrowly in $1927 .{ }^{163}$

The final terms of the act provided that other naturalized persons would be considered as citizens, not as natural born citizens like the children. That difference may reflect an important issue of the debate - whether naturalization should grant the rights of a natural born person under state law, particularly the right to own and inherit land, progressively (as the states generally did prior to the Constitution's adoption) or all at once. ${ }^{164}$ Congress may have intended to ensure that the children received all of the rights of a natural born person under state law at once. For these and other reasons, ${ }^{165}$ the

163 See Weedin v. Chin Bow, 274 U.S. 657, 664 (1927) (finding it "very clear" that the paternal residency proviso in the legislation at issue had "the same meaning as that which Congress intended to give it in the Act of 1790" with an exception not relevant) and 666-67 (both pre-natal and post-natal paternal residency are possible interpretations of the proviso's requirement, but the former is "more in accord with the views of the First Congress."). Neither the Court's opinion nor any brief filed with the Court in the case even suggested that the term "considered as natural born citizens" in the Naturalization Act of 1790 meant only citizens at birth, which would have made it impossible for postnatal paternal residency to satisfy the proviso. All five courts that previously considered the issue had found that post-natal paternal residency satisfied the requirement as renewed in the subsequent legislation. See State v. Adams, 45 Iowa 99 (1876), Johnson v. Sullivan, 8 F.2d 988, 989 (1st Cir. 1925) (affirming lower court ruling and finding that if Congress had intended the paternal residency proviso to require pre-natal residency it would have so provided in the statutory language), and Weedin v. Chin Bow, 7 F.2d 369 (9th Cir. 1925) (affirming lower court ruling), rev'd, 274 U.S. 657 (1927) (reversing based in part on reading the act in pari materia with 1907 legislation and in part on incomplete legislative history from the First Congress that lacked the history of H.R. 40 cited above). See also John Vlahoplus, On the Meaning of "Considered as Natural Born," WAKE Forest L. REv. ONLINE (Apr. 5, 2017) (eighteenth century prescriptive use of "shall be considered as natural born" merely naturalized persons or granted limited rights of the natural born), http://wakeforestlawreview.com/2017/04/on-the-meaning-of-considered-as-natural-born/; and Rob Natelson, Claims that Senator Cruz is not "Natural Born" Need to be Taken Seriously, Originalism Blog (Jan. 11, 2016) (Congress may have used "considered as natural born" to confer private rights and benefits, not to explain or define the constitutional term), http://originalismblog.typepad.com/the-originalism-blog/2016/01/claims-that-sencruz-is-not-natural-born-need-to-be-taken-seriouslyrob-natelson.html.

164 See, e.g., 12 History, supra note 31, at 149, 158, and 9 Documentary History of the First Federal Congress of the United States of America 220-23, 494 (Kenneth R. Bowling \& Helen Veit eds., 1988). For state practices of granting rights progressively prior to the Constitution, see supra note 80 and KeTtNer, supra note 22, at 215-19. See also McManamon, supra note 6, at 332-33 (importance of real property rights to the Naturalization Act of 1790).

165 In another approach, Clement, Katyal and others argue that it would be absurd to suggest that children born to Americans abroad are not natural born because John Jay suggested adding the natural born requirement, he had children while serving abroad on diplomatic missions, and he would not have intended his own children to be excluded from presidential 
procedural theory cannot provide the doctrinal or historical definition of a natural born citizen.

\section{Hybrid theory}

Michael D. Ramsey asserts a hybrid theory of eligibility under which Congress may confer presidential eligibility by naturalization but only to persons granted citizenship at birth to American citizen parents, arguing that this rule is consistent with British practice and with the purpose of the eligibility clause. ${ }^{166}$ He claims that in England with only one exception "[t]he only persons granted full natural born status (including eligibility to office) by statute were those who had material connections to England at birth, namely that their parents or grandparents were English subjects." 167 By the eighteenth century those children "were born under the allegiance and protection of the monarch (what the common law required of a 'natural born citizen') even though not born in the monarch's lands."168 All other naturalized persons were subject to the disabling clause mandated by the Act of Settlement that prohibited them from holding office. The only exception was the titular provision of the Act of Ann. that naturalized Protestant immigrants without imposing the disabilities, and Parliament quickly repealed that provision, "indicat[ing] that Parliament realized it had overstepped its authority in " that act. ${ }^{169}$ Following English practice would also prevent Congress from conferring "natural born status on a particular individual without . . . making all similarly situated persons equally eligible" because "Parliament did not exercise its naturalization power in this way." 170 British and American law and practice preclude this theory.

eligibility. See, e.g., Clement \& Katyal, supra note 140, at 163. This claim fails because Jay's children were natural born under the common law rule. See, e.g., McManamon, supra note 6, at 342, Elhauge, supra note 6, at 37-38, and House of Lords Journal (Jan. 23, 1667), in 12 Journal of the House of Lords: 1666-1675, at 86-87 (London, 17671830) (common law rule and ambassadors), http://www.british-history.ac.uk/lords-jrnl/ vol12/pp86-87. Neither of the prevalent justifications involved transmission by right of blood. One understood the house of the ambassador to be the territory of the home sovereign (not the host sovereign). See, e.g., Letter from John Adams to William Steuben Smith, National Archives (May 30, 1815), http://founders.archives.gov/documents/ Adams/99-03-02-2874, and De Geer v. Stone (1883) 22 Ch. D. 243, 254. The other considered a principle of postliminium to deem the child to have been born under the king's allegiance. See Blackstone, supra note 42, at 361 (referring to ambassadors' children as "natural subjects" at common law). Children born to parents adhering to the United States within but not under its jurisdiction because of hostile foreign occupation become citizens "by a sort of postliminy." See Inglis v. Trustees of Sailor's Snug Harbor, 28 U.S. 99, 156 (1830) (Story, J., dissenting on other grounds). They might be natural born by analogy to Blackstone's principle of postliminium.

166 See Michael D. Ramsey, The Original Meaning of "Natural Born" at 33, 36, 38 and n.141 (2016), (unpublished manuscript) (revised version forthcoming $20 \mathrm{U}$. PA. J. Const. L. (2018)). For an earlier articulation of the hybrid theory see Michael Hennessy, Letter to the Editor, Gen. Meade's Citizenship, New York Times (Aug. 1, 1863), http:// www.nytimes.com/1863/08/01/news/gen-meade-s-citizenship.html.

167 Ramsey, supra note 166, at 36.

$168 I d$. at 21.

169 Id. at 22 n.83.

$170 I d$. at 36. 
Parliament could not have overstepped its authority in the Act of Ann. because no Parliament can bind its successors. ${ }^{171}$ It repealed the titular provision because destitute Protestant refugees flooded England and built a tent city of some fifteen thousand immigrants around London, ${ }^{172}$ not because it thought it had overstepped its authority. It left intact an earlier statute that naturalized sailors without imposing the disabilities. ${ }^{173}$ Subsequent acts of Parliament also naturalized particular individuals of high rank without imposing the disabilities. ${ }^{174}$ Lord Brougham and Vaux publicly criticized British practice as "absurd and inconsistent" for exempting particular foreigners of high rank who were the most likely to influence the government while enforcing the disabilities against naturalized persons "of the most insignificant station" who could not possibly exert any influence. ${ }^{175}$

In addition, Parliament allowed exemptions from other prohibitions in the Act of Settlement including that of foreigners holding offices or positions of trust and one that the drafter of a later nationality act called the most important - the prohibition on sitting in the House of Commons while holding any office or place of profit under the crown. ${ }^{176}$ The threat of crown patronage to parliamentary independence is apparent.

Moreover, foreign-born children of British parents were not born under the allegiance of the monarch in the eighteenth century. The very basis of the Acts was that the children were born out of the monarch's allegiance and therefore could only

171 See, e.g., Blackstone, supra note 42, at 90 ("ACTS of parliament derogatory from the power of subsequent parliaments bind not.”), and Select Committee, supra note 126, at 17 (A.W. Kinglake, Esq.) (the Act of Settlement's provision that purports to bind future Parliaments "is as a legal enactment simply null and void.”). Moreover, the Act of Settlement technically did not even purport to apply to naturalizations during Anne's reign. See 12 \& 13 Will. 3 c. 2 , cl. 3.

172 See, e.g., The History of the last Session of Parliament, \&c., 32 The London Magazine, or, Gentlemans's Monthly Intelligencer 240 (1763), http://hdl.handle.net/2027/ mdp.39015021269322, and A.H. Carpenter, Naturalization in England and the American Colonies, 9 Аm. Hist. Rev. 288, 293 (1904).

173 See 6 Ann. c. 37, cl. 20 (1707), https://hdl.handle.net/2027/mdp.39015065182050. This act had no termination date. Clause 20 might have lapsed by 1740 , or it might have been repealed by implication in 13 Geo. 2 c. 3 (1740), https://hdl.handle.net/2027/ mdp.39015035134090. However, some considered it operative in the nineteenth century. See Select Committee, supra note 126, at 15-17 (regarding the "6th of Anne”). The continuing validity of this act was important to the Founders, in particular the clause exempting from impressment persons serving on ships employed in America. See, e.g., Keith Mercer, The Murder of Lieutenant Lawry: A Case Study of British Naval Impressment in Newfoundland, 1794, 21 NewfoundLAND AND LABRAdOR Studies 255 (2006), https://journals.lib.unb.ca/index.php/nflds/article/view/10153/10455.

174 See, e.g., 7 Geo. 2 c. 3 \& 4 (1733/34) (the Prince of Orange), https://hdl.handle.net/2027/ mdp. $39015035134082 ; 4$ Geo. 3 c. 4 \& 5 (1763) (the Prince of Brunswick), https://hdl. handle.net/2027/njp.32101075729267; 1 William Blackstone, Commentaries on the LAWs of ENGLAND 374 (RI. Burn, LL.D, ed., 9th ed. 1783) (containing Blackstone's final corrections), https:/hdl.handle.net/2027/mdp.35112203968070; and SELECT CoMmITTEE, supra note 126 , at 8.

175 See Select Committee, supra note 126 , at 8.

176 See, e.g., id. at 4, 8-9, 12-13 and 17; A Country Gentleman, Miscellaneous Thoughts, Moral and Political etc. 9, 24 (1745) (placemen sitting in Parliament), https:// books.google.com/books?id=ck9gAAAAcAAJ; and 12 \& 13 Will. 3 c. 2, cl. 9 (Act of Settlement limitations). 
be deemed natural born by a legal fiction. ${ }^{177}$ The Acts only applied to those born out of allegiance, ${ }^{178}$ and the House of Lords decision in Leslies specifically states that " $[\mathrm{t}]$ he common law right, and the statutory right, are set in opposition to one another." 179 The children's rights (including any right to protection) followed only from statutory grant. ${ }^{180}$ And, as described below in Part III.C.3, even when the Acts applied they did not always confer the rights of a British subject under international law and may not have imposed any obligations from birth.

Finally, the Act of Settlement's parental exemption was not limited to persons naturalized at birth. The Act of Settlement predated the British nationality acts, and it was not widely accepted that the Act of Edw. III naturalized foreign-born children of English parents; consequently, many foreign-born children of English parents were post-natally naturalized prior to the Act of Ann. ${ }^{181}$

The First Congress was well aware of British practice including Parliament's attempts to impose the disabilities, its failed general system of naturalization, and the fact "that, to this day, even of their meritorious naval and military characters they make an exception, as to sitting in parliament, \&c. . . ."182 Contrary to Ramsey's and others" assertions, ${ }^{183}$ there was no such thing as "full natural born status" in British law. There were only natural born subjects in fact (subjects by birth) and persons deemed to be natural born by a parliamentary fiction (subjects by statute). Some subjects by statute could hold office and others could not, depending entirely on the will of Parliament. By overriding the Act of Settlement in subsequent statutes Parliament exercised its supreme authority and properly authorized persons to hold office. If the United States followed British practice then Congress could grant presidential eligibility to anyone at any age, and federal officers could sit in Congress contrary to the constitutional prohibition. ${ }^{184}$ However, Congress is not supreme. It cannot alter the constitutional definition of "natural born." For these and other reasons, the hybrid theory cannot provide the doctrinal or historical definition of a natural born citizen. ${ }^{185}$

177 See, e.g., Doe dem. Thomas v. Acklam (1824) 26 Rev. Rep. 544, 556 (Abbott, C.J.) (out of allegiance), and Dundas v. Dundas (1839) 12 Scot. Jur. 165, 171 (Moncreiff, J.) (fiction).

178 See 7 Ann. c. 5, cl. 3 ("born out of the ligeance of her Majesty"), 4 Geo. 2 c. 21, cl. 1 ("born out of the ligeance of the Crown"), 13 Geo. 3 c. 21 , cl. 1 ("born . . out of the Ligeance of the Crown”), and Calvin's Case (1608) 7 Co. Rep. 1a, 4b ("Ligeance is a true and faithful obedience of the subject due to his Sovereign.").

179 Leslies v. Grant (1763) 2 Pat. 68, 77.

180 See, e.g., In re Willoughby (1885) 30 Ch. D. 324, 327-29 (child was "born out of the allegiance of the Crown" but was "entitled by statute" to the rights of a natural born subject, including the right to the appointment of a guardian), http://hdl.handle. net/2027/osu.32437121370957, aff'd, (1886) 53 LT 926, https://hdl.handle.net/2027/ osu.32437121366849.

181 See, e.g., McManamon, supra note 6, at 323-25. The Act of Settlement also exempted denizens who were born of English parents. See An act for the further limitation of the crown, and better securing the rights and liberties of the subject, $12 \& 13$ Will. 3 c. 2 , cl. 3 (1700). The monarch made persons denizens after their births.

182 See 12 History, supra note 31, at 162-63.

183 See, e.g., Gordon, supra note 65, at 7-8.

184 See U.S. Const. art. I, § 6, cl. 2.

185 The same judicial precedents, constitutional history, and legislative history that preclude the procedural theory also preclude the narrower hybrid theory. 


\section{CONSISTENCY With ENGLish AND British InTERPRETATIONS}

The Supreme Court instructs us to interpret the term "natural born citizen" by reference to English common law, which the Court interprets to mean nationality "by birth" - that is, nationality conferred by birth within and under the jurisdiction of the sovereign. ${ }^{186}$ The body of American authorities beginning in the colonial era and including Inglis, Minor, Elk, Wong Kim Ark and Elg is extensive and should be sufficient to determine the constitutional definition without further reference to English and British authorities and regardless of any disputes over the proper interpretation of those original authorities. However, the lack of a Supreme Court decision on presidential eligibility might allow one to appeal to the original authorities to dispute the Court's rule of construction (that the common law provides the definition) and its specific interpretation of the common law (nationality "by birth"). In any event, comparing the Court's rulings and American constitutional history with the English and British interpretations shows that they are broadly consistent, although it also reveals some significant inconsistencies in English and British doctrine.

\section{A. The Common LAW}

The Court's rule of construction is consistent with the eighteenth century rule that a known legal term used in an act of Parliament takes its common law meaning, a rule with which the Founders were likely familiar. ${ }^{187}$ It is also consistent with the British rulings that the common law provides the definition of "natural born" in the British nationality acts and with Parliament's concurrence in the Act of Geo. III.

The Supreme Court's formulation of the common law rule is consistent with the standard British interpretation. The Court routinely relies on Blackstone to determine English law, ${ }^{188}$ and Blackstone defines natural born subjects at common law as those born within the king's dominions and allegiance because of the natural allegiance that they owe him in return for the protection he affords them during their infancy when they cannot protect themselves. ${ }^{189}$ The Court's formulation and its definition of nationality "by birth" are also consistent with Acklam, the U.K. Home Office's view of the common law, and the leading twenty-first century British nationality

186 See supra notes 23-26.

187 See, e.g., 4 Matthew Bacon, A New Abridgment of the Law 647 (1759), https:// archive.org/details/newabridgementof04baco. John Adams cited rules of construction from volume 4 in 1773. See John Adams, Notes of Statutes and Authorities: Court of Vice Admiralty, Boston, National Archives (Feb. 1773) (citing 4 Bac. Abr. 652), http://founders.archives.gov/documents/Adams/05-02-02-0006-0009-0002. Bacon's Abridgment was often used in the American colonies. See, e.g., William B. Stoebuck, Reception of English Common Law in the American Colonies, 10 WM. \& MARY L. Rev. 393, 416 (1968).

188 See, e.g., Alden v. Maine, 527 U.S. 706, 715 (1999).

189 Blackstone, supra note 42, at 354, 357. See also United States v. Wong Kim Ark, 169 U.S. 649, 670 (1898) (“'The acquisition,' says Mr. Dicey, (p. 741) 'of nationality by descent, is foreign to the principles of the common law ...'”), McManamon, supra note 6, at 320, and Elhauge, supra note 6, at 16. 
treatise. ${ }^{190}$ The Court's decisions are also consistent with British understanding of American constitutional law. Britain recognized even before Minor that the United States had inherited the English common law rule based solely on place of birth, and it observed that both nations recognized the inconveniences of the rule in the case of children born to their subjects abroad and therefore both enacted remedial legislation to ameliorate its effects. ${ }^{191}$

\section{B. NATURALIZATION AND NON-TRANSMISSION OF NATIONALITY}

American recognition that the Acts were not declaratory of the common law is consistent with the standard British interpretation. ${ }^{192}$ American recognition that they were naturalization acts is consistent with the text of the Act of Geo. III ("any Person naturalized by virtue of this Act"); ${ }^{193}$ the opinion of Lord Kenyon, Chief Justice of the King's Bench, in Duroure (the Acts extend "the privileges of naturalization "); 194 Blackstone's Commentaries (characterizing the Act of Ann. as "naturalizing the children of English parents born abroad"); ${ }^{195}$ the House of Lords in Leslies; ${ }^{196}$ the Home Office; ${ }^{197}$ a select committee of the House of Commons; ${ }^{198}$

190 See supra note 132 and accompanying text (Acklam); Fransman, supra note 67, at 130 ("birth within the Crown's dominions and allegiance . . . conferred British subject status by birth' (in modern parlance).") (emphasis omitted) and 131 ("children born in foreign countries were aliens at common law irrespective of their parents' nationality.") (emphasis in original); and British Nationality: Summary, §§ 1.3.1 ("At Common law, subject status was acquired by birth within the Crown's 'dominions and allegiance'.") and 1.4.2 ("The general position was that children born in foreign countries were aliens regardless of the nationality of their parents."), https://assets. publishing.service.gov.uk/government/uploads/system/uploads/attachment_data/ file/632300/britnatsummary.pdf. The U.K. Home Office confirmed in correspondence with the author that the summary reflects its understanding of the development of British nationality law.

191 See Report of the Royal Commissioners for Inquiring Into the Laws of Naturalization AND Allegiance xiii (1869), http://hdl.handle.net/2027/umn.31951002090907t.

192 See, e.g., Blackstone, supra note 42, at 354 and 361; Doe dem. Duroure v. Jones (1791) 4 T.R. 300, 308 (Kenyon, C.J.); and Ex parte Carlebach [1915] 3 K.B. 716, 723. See also McManamon, supra note 6, at 339, and Elhauge, supra note 6, at 28. Both the House of Lords and the Supreme Court have rejected claims that Chief Justice Hussey concluded the contrary in the time of Richard III, finding that he relied on the Act of Edw. III rather than the common law. See Leslies v. Grant (1763) 2 Pat. 68, 76, and Wong Kim Ark, 169 U.S. at 669.

19313 Geo. 3 c. 21 , cl. 3.

194 Duroure, 4 T.R. at 309 (Kenyon, C. J.).

195 Blackstone, supra note 42, at 363.

196 Leslies, 2 Pat. at 77 (fear that a broad interpretation of the Act of Ann. might naturalize half of Europe).

197 Home Office File HO 45870 159961, Minutes of Dec. 11, 1907, Naturalization of Prince Louis and the late Prince Henry of Battenberg ("children born abroad of persons who are 'naturalized' by the general statute 13 Geo III c. 21 are undoubtedly aliens."), http://www.heraldica.org/topics/britain/TNA/HO_45_870_159961.htm.

198 The committee categorizes the Act of Edw. III and the British nationality acts as "Naturalization Acts" conferring "Naturalization by birth" that Parliament enacted because of doubts "whether the children of English subjects born out of the liegeance 
and other authorities. ${ }^{199}$ "Naturalization" applied only to aliens, the word meaning "where a Person who is an Alien, is made the King's natural Subject by Act of Parliament, whereby one is a Subject to all Intents and Purposes, as much as if he were born so ....." ${ }^{200}$

The principle that foreign-born children of American citizens are aliens to the Constitution is consistent with British law under which children born to subjects abroad were aliens and could only be deemed subjects if they met the terms of a nationality statute. ${ }^{201}$ The principle that citizenship does not descend from parent to child is consistent with the British rule that "nationality is a status which must be acquired by or conferred upon the individual himself. It is not a status which can be transmitted to him by his parent." 202 Just as the Supreme Court said of common naturalization statutes, ${ }^{203}$ a British court explained that the child "does not really acquire his status by reason of his descent." 204 This conclusion is consistent with the stated policy rationale of the Acts. In Fitch v. Weber the court rejected a claim that general paternal disloyalty could prevent the Acts from applying to a child, explaining that " $[\mathrm{t}]$ he privilege conferred by the statutes . . . is the privilege of the children and not of the father, and is conferred upon the children for the benefit of the state. "205 The Acts conferred a personal privilege; they did not recognize or create a right of blood.

\section{INCONSISTENCIES IN ENGLISH AND BRITISH INTERPRETATIONS}

\section{Common law rule}

The standard interpretation of the common law rule is not undisputed. Some believed that the Act of Edw. III declared the common law. ${ }^{206}$ Others asserted

of the King were entitled by the common law to" the benefit of being English subjects. See Select Committee, supra note 126, at ix-x. Naturalization by birth would not be necessary if the children were common law subjects by birth. But see infra note 238 and accompanying text (Calvin "naturalized" by procreation).

199 See, e.g., Journals, supra note 82 (unpaginated) (indexing under "Naturalization" the 1784 proposed "Bill for declaring the Children of British Mothers natural-born Subjects though born Abroad”). See also Elhauge, supra note 6, at 28.

$200 \mathrm{~J}_{\mathrm{ACOB}}$, supra note 35 (unpaginated) (emphasis in original).

201 See, e.g., Dundas v. Dundas (1839) 12 Scot. Jur. 165, 169 (Jeffrey and Mackenzie, JJ.). See also argument of counsel in Fitch v. Weber (1847) 6 Hare 51, 55 (foreign-born descendent of a British subject must "show some statute by which he is relieved from the effect of his alien character."), http://hdl.handle.net/2027/uc1.b5063979.

202 Ex parte Carlebach [1915] 3 K.B. 716, 729 (Lush J.). In Carlebach a son claimed British nationality arguing that the statute naturalizing his father granted the father all of the rights and capacities that a natural born subject can enjoy or transmit and that the British nationality acts gave natural born subjects the right to transmit nationality to their foreign-born children. The court rejected this argument because nationality cannot be transmitted.

203 See, e.g., United States v. Wong Kim Ark, 169 U.S. 649, 665 (1898), and Miller v. Albright, 523 U.S. 420, 434 n.11 (1998).

204 Carlebach, 3 K.B. at 723 (Reading, C.J.).

205 Fitch, 6 Hare at 62.

206 See, e.g., cases cited in United States v. Wong Kim Ark, 169 U.S. 649, 669 (1898). 
that foreign-born children were natural born at common law if their father was English, ${ }^{207}$ so that the Act of Edw. III narrowed the law by requiring both parents to be English. Some even concluded that it was impossible to state the common law rule with precision and defaulted to statutory rules for convenience. ${ }^{208}$

\section{Effect of post-natal naturalization}

English and British authorities differed on the effect of post-natal naturalization. Naturalization deemed a person to be a natural born subject as if born in the realm. Naturalization in England gave the subject a "civil birth" there; that is, he had "a civil birth given him by Act of Parliament . . . ."209 Some asserted that this made one a natural born subject. Lord Hale opined that "birth here" and post-natal naturalization of a son "is all one" because naturalization makes him "a natural born son, (for so he is, as I have argued by his naturalization)." 210 Several pre-Revolutionary British statutes stated that a naturalized person became a natural born subject. ${ }^{211}$ The well-known Lex Parliamentaria, which Thomas Jefferson considered to be the best parliamentary work, explained that Parliament's naturalization of an alien "make[s] him a Subject born." 212 A court even held that post-natal naturalization made one liable to a charge of high treason under a statute that only applied to persons born within the realm. ${ }^{213}$

However, many considered naturalization to be merely a legal fiction that could not make one a natural born subject because one "cannot have two natural Sovereigns . . . no more than two natural fathers, or two natural mothers. "214 The critical feature of a natural born subject was the natural allegiance she owed from her actual birth within the realm in exchange for the monarch's protection there beginning at birth. ${ }^{215}$ The king provided protection within his country, and therefore

207 See Leslies v. Grant (1763) 2 Pat. 68, 78 (Hardwicke, J.).

208 See id. at 76-78 (Pratt, C.J.).

209 See Collingwood v. Pace (1661) 124 Eng. Rep. 661, 665 and 688 (Bridgman, C.J.). See also id. at 686 (naturalization as "legal birth").

210 See Collingwood v. Pace, 86 Eng. Rep. 262, 271.

211 See 13 Geo. 2 c. 7, cl. 6 (1740) ("shall become a natural born subject of this kingdom by virtue of this act"), http://hdl.handle.net/2027/mdp.39015035134090; 20 Geo. 2 c. 44, cl. 5 (1747), http://hdl.handle.net/2027/mdp.39015035134116; and 13 Geo. 3 c. 25 (1773), http://hdl.handle.net/2027/mdp.39015039741080.

212 See Letter from Thomas Jefferson to Thomas Mann Randolph, Jr., National Archives (May 30, 1790), http://founders.archives.gov/documents/Jefferson/01-16-02-0264 (describing Lex Parliamentaria), and George Petyt, Lex Parliamentaria 75 (3d ed. 1748) (Parliament "may Naturalize a meer Alien, and make him a Subject born."), https://books.google.com/books?id=ishCAQAAMAAJ.

213 See The Trial of George Busby at Derby Assizes, for High Treason, being a Romish Priest (1681), 8 St. Tr. 525, 534, 536 (Assiz.) (as an alternative ground for liability in addition to actual birth within the realm, which king's counsel alleged but Busby denied), https://hdl.handle.net/2027/uc1.31175023755872.

214 Craw v. Ramsey (1670) 124 Eng. Rep. 1072, 1075 (Vaughan, C.J.). See also Blackstone, supra note 42, at 361 ("every man owes natural allegiance where he is born, and cannot owe two such allegiances, or serve two masters, at once.").

215 See, e.g., Craw, 124 Eng. Rep. at 1074-75 (Vaughan, C.J.). Vaughan did not claim that natural law imposed natural allegiance. On the contrary, he asserted that "a man owes no liegeance excluding all civil law ...." Id. at 1074. Instead, he considered natural 
the newborn's place of birth was her natural country and her allegiance to its king was natural allegiance.

\section{Operation and effects of the Acts}

Despite rulings that parents do not transmit British nationality to their children by descent, some refer to parental transmission of nationality by descent for two generations under the Acts. ${ }^{216}$ This might raise the question whether the Acts did "in fact make the beneficiaries actual natural born subjects (as opposed to merely giving the rights of natural born subjects)." ${ }^{217}$ The only apparent controlling authorities that pre-date the Constitution, Leslies v. Grant and the Act of Geo. III, demonstrate that the Acts did not in fact make one natural born or even British. Consistent with those authorities, Blackstone made clear before Independence that the Acts only "deemed" their beneficiaries to be natural born. ${ }^{218}$

Nineteenth century and later general usage of the term "natural born subjects" varies, however. The leading twenty-first century treatise states that "[t]he terminology did not distinguish between acquisition by birth and acquisition by descent; instead, anyone born a subject was termed a 'natural-born' subject. "219 Yet the U.K. government's British nationality summary describes only the person born

allegiance to be natural in the same sense as "a country where a man is born, is his natural country, or the language he first speaks, is his natural tongue . . ." Id.

216 See, e.g., Fransman, supra note 67, at 131-32.

217 See Ramsey, supra note 166, at 21-22. Ramsey asserts that the Act of Ann. redefined "natural born" so that the Acts actually made the children natural born subjects. See id. at 18 and 20 .

218 Blackstone originally wrote in 1765 that under "modern statutes" the children "are now natural-born subjects themselves, to all intents and purposes, without any exception" unless their father had been tainted. See Blackstone, supra note 42, at 361. In 1775 he revised the statement to reflect the authority of the Act of Geo. III, explaining that under "modern statutes" the children "are now deemed to be natural-born subjects themselves, to all intents and purposes" unless their father (or paternal grandfather) had been tainted. See BlacKstone, supra note 134, at 373 (adding "deemed to be" and deleting "without exception"). Subsequent editions retained the revised explanation. See, e.g., Blackstone, supra note 174, at 373 . Similarly, Francis Plowden initially wrote that the Act of Edw. III made children "in fact and law . . . true native subjects" and that the Acts of Ann. and Geo. II made persons "natural born subjects by the statute law" just as others were "natural born subjects by the common law". See Plowden, supra note 101, at 74, 161-62 (emphasis in original). However, after considering the Act of Geo. III further he concluded that the statutes did not make the children natural born subjects; rather, there remained "a strange relict of alienage in them." FRANCIS Plowden, A Supplement to the Investigation of the Native Rights of British Subjects 134 (1785), https://hdl.handle.net/2027/osu.32437121568725. Leslies, the Act of Geo. III, Plowden and Blackstone contradict the three alternative claims that the Acts declared existing law, recognized persons to be natural born, or made them in fact natural born. Clement, Katyal and Ramsey rely on the obsolete first edition of Blackstone to argue that the Acts actually made the children natural born. See Ramsey, supra note 166, at 4 n. 20 and 20 (citation dated 1765) and Clement \& Katyal, supra note 140, at 162 n.7 and accompanying text (undated citation with page references appropriate only to the 1765 edition).

219 Fransman, supra note 67, at 131 (emphasis in original). 
in the U.K. as a subject born. ${ }^{220}$ Some nineteenth century authorities assert that the Acts deemed one to be natural born by a legal fiction. ${ }^{221}$ Lord Moncreiff expressed that opinion in 1839 :

All the three Acts necessarily assume, that the persons who are thereby declared to be natural-born subjects of Great Britain, and to be taken and accounted as such, are really not so in the common meaning of the term. The very basis of the enactments is, that they are born out of the liegance of the British Sovereign, and so are not naturally his subjects, but, by the laws of nations, the natural-born subjects of a foreign state. It is apparent therefore, that the descendants of the first generation always must be ex hypothesi, in that condition — that, by their birth, they are the subjects of another power, and not the subjects of Britain ... and the emphatic terms employed in declaring them to be natural-born subjects, import a very powerful fiction of the law, but still nothing but a fiction, for effecting the object in apparent consistency with the general principle of the law of alienage. ${ }^{222}$

Lord Cuninghame further explained that the Acts "appear to have been framed purposely to encourage and bring back persons of British extraction, born aliens, to their allegiance, and still to bestow on them their inheritance in this country, if any descended to them. "223 In this view a natural born subject was only one who became a subject by birth, not one who became entitled to the rights of a natural born subject by statute, even by a statute naturalizing him at birth. ${ }^{24}$ The latter

220 Using "BS" for "British Subject," it describes the grandfather born in the U.K. as "BS - Born" and the father and grandchild born abroad as "BS - Descent". See British Nationality: Summary, supra note 190, at $\S 2.4$.1. For an equivalent American usage, see, e.g., Lum Man Shing v. United States, 29 F.2d 500, 501 (9th Cir. 1928) (immigration rule applicable to United States citizens "by birth or descent"). Dicey sets forth a rule similar to Blackstone's original explanation, which might support Fransman's interpretation; however, his "Comment and Illustrations" explain that the Acts "deemed" the children to be natural born, quoting the 14th edition of Stephen's Commentaries, which quotes Blackstone's revised explanation. See A.V. DicEY, A Digest of the Laws of England With Reference to the Conflict of Laws (2d ed. 1908) at $\operatorname{xxxix}-\operatorname{xxxx}$ (general rule and exceptions), 168-69 ("Comment and Illustrations" on the general rule), 168 n.3, and 169 n.2, http://hdl.handle.net/2027/cool.ark:/13960/ t85h8373k; 2 Henry John Stephen, Mr. Serjeant Stephen's New Commentaries on the Laws of England (Partly Founded on "Blackstone.”) 348-49 (14th ed. 1903), https:/hdl.handle.net/2027/uc2.ark:/13960/t8gf0xb9t; and supra note 218 (Blackstone's original and revised explanations). $C f$. Elhauge, supra note 6, at 17 n.4 (disputing a claim that Dicey supports derivative citizens' eligibility).

221 See, e.g., Dundas v. Dundas (1839) 12 Scot. Jur. 165, 171 (Moncreiff, J.). Cf. supra notes 130, 133 and accompanying text (the Acts did not make their beneficiaries natural born subjects truly and actually, in fact, or in the common meaning of the term) and infra notes 236-37 and accompanying text (the Acts only made one a British subject in an artificial or technical sense and not in the ordinary meaning of the term or under the law of nations).

222 Dundas, 12 Scot. Jur. at 171 (Moncreiff, J.) (emphasis in original).

223 Id. at 167 (report referring the case to the whole court).

224 Blackstone made clear before Independence that the Acts "deemed" persons to be natural born, supporting this view. See supra note 218 . 
was by nature an alien and by birth the subject of another power, not a subject of Britain.

A New York court described British law similarly in a decision involving custody of a child born in the United States to a natural born English father. The court explained that the Acts of Ann. and Geo. II were enabling statutes of naturalization that merely deemed the child to be natural born by a parliamentary fiction in order to give her the rights of a natural born subject but could not affect her national character because that would conflict with the fundamental rule that natural allegiance is that which "natural born subjects . . by natural law owe to the country of their nativity ...."225 Even persons naturalized by the Acts could explain this distinction. The foreign-born Rev. Joseph Blanco White described his paternal grandfather in 1829 as "a natural born subject, a native of Waterford" but himself as only a "British subject" who has the "right to all the privileges of a natural born subject . . . "226 He carried copies of the Acts to the polls to prove his right to vote because people considered him to be an alien. ${ }^{227}$

However, other nineteenth century authorities use language that can be interpreted to support both views. Lord St. Leonards writes of the Act of Geo. II that "in order to entitle an alien to be treated as a natural-born subject, he must at the time of his birth, although a foreigner born, be the son of a father who was a natural-born subject, ${ }^{228}$ acknowledging that the child is an alien whom the act merely entitles to be treated as a natural born subject. In the same opinion, however, he writes "[n] obody will dispute that under that Act a legitimate child, the child of a natural-born subject, becomes a natural-born subject from the moment of his birth" - suggesting that naturalization under the Acts actually made one a natural born subject.229 Lords Jeffrey and Mackenzie write that "natural-born is but an adjective, which imports nothing more than the exclusion of those subjects, to whom it cannot be applied. It means those who were born subjects, certainly", suggesting that anyone naturalized at birth was natural born. ${ }^{230}$ However, they also write in the same opinion that the term "natural born subjects" in the Acts of Ann.

225 See Ex parte Dawson 3 Bradf. Ch. 130, 136-38 (N.Y. Surr. Ct. 1855), http://hdl.handle. net/2027/mdp.35112102507474. Cf. Weedin v. Chin Bow, 274 U.S. 657, 660 (1927) (the Acts of Ann. and Geo. II deemed children natural born, and the Act of Geo. III extended this to the next generation). An English court considered its jurisdiction over an infant born and living in France in In re Willoughby (1885) 30 Ch. D. 324, aff'd, (1886) 53 LT 926. The child met the paternal requirement of the Act of Geo. III; the court found that although she was "born out of the allegiance of the Crown" she was "entitled by statute to all the rights of a natural-born British subject" including the right to protection by the sovereign acting as parens patriae; and it appointed a guardian while acknowledging that it would work in comity with French courts and respect their decision on control over the child. Willoughby, 30 Ch. D. at 327-29, relying on Hope v. Hope (1854) 52 Eng. Rep. 340 (same result under the Acts of Ann. and Geo. II), https://hdl.handle.net/2027/inu.30000029142910.

226 See 1 Joseph Blanco White, The Life of the Rev. Joseph Blanco White 456 (1845), http://hdl.handle.net/2027/uc1.\$b784570.

227 Id.

228 See Shedden v. Patrick (1854) 149 Rev. Rep. 55, 90.

229 Id. at 91.

230 Dundas v. Dundas (1839) 12 Scot. Jur. 165, 170 (emphasis in original). Alternatively, by "born subjects" they might have meant "born subjects" as in the Attorney-General's Leslies argument - that is, a common law "subject born." See supra notes 1 and 117 and accompanying text. 
and Geo. II means only persons who become subjects from nativity in the realm, not from statutes or patents of naturalization, ${ }^{231}$ demonstrating their view that a father who had been naturalized under those acts was not in fact natural born.

The nearest interpretation of British law on point by a Founder is by Thomas Jefferson who wrote that the Acts of Edw. III, Ann. and Geo. II naturalized foreignborn children and that "here are statutes first making the son born abroad a natural subject, owing allegiance." ${ }^{32}$ It is unclear whether Jefferson meant to distinguish children naturalized under the Acts from persons naturalized under other acts of Parliament. Post-natally naturalized subjects owed the allegiance of a natural subject, and Jefferson's esteemed Lex Parliamentaria states that naturalization by Parliament makes an alien "a Subject born."233

Some of the inconsistencies might be explained by the impossibility of reconciling the common law's rationale of natural allegiance with the policy rationale of the Acts (to increase national wealth by attracting limited classes of foreign-born offspring to Britain). The clearest example was the view of some authorities that the Acts did not grant any privileges or impose any obligations until a beneficiary affirmatively exercised the privileges. Until then the beneficiary was at most only technically a British subject, was not entitled to the rights of a British subject under international law, and would not be guilty of treason for bearing arms against Britain in the service of his native country. ${ }^{234}$ The Crown asserted in Drummond's Case, for example, that the Acts only "confer the benefits of naturalization in Great Britain on those who come there and avail themselves of them" and "cannot be held to naturalize a man who ... passes his whole life in a foreign country," so that one who never claimed their privileges could not be guilty of treason for bearing arms against Britain. ${ }^{235}$ The Crown argued in the

231 Dundas, 12 Scot. Jur. at 170.

232 Jefferson, supra note 1.

233 See supra note 212.

234 See infra notes 235-37 and accompanying text.

235 See Drummond's Case (1834) 12 Eng. Rep. 492, 497 (argument of King's Advocate), http://hdl.handle.net/2027/coo.31924064793387. See also Dundas, 12 Scot. Jur. at 171 (Moncreiff, J.) (the Acts do not impose involuntary obligations because "neither the Queen nor Parliament can command the allegiance of a man who was born the subject of another state"; one could not be guilty of treason for bearing arms against Britain in defense of his native land merely because "he might, if he had chosen, have enjoyed the privileges of a natural-born British subject" under the Acts) (emphasis in original), and 190 Great Britain, Hansard's Parliamentary Debates 2006 (1868) (Sir Roundell Palmer) (the Acts confer benefits but do not impose burdens absent consent; to construe them to make persons "in every respect" natural born is "absurd"), https://hdl.handle. net/2027/osu.32435069737625. Two other Members of Parliament agreed with Palmer; one believed that "some doubt exists" on the question; and one asserted that the Acts of Ann. and Geo. II imposed allegiance and that the equivalent U.S. statute made foreignborn children of citizen fathers eligible to the presidency. See id. at 1984-2005. Palmer had served as Attorney-General for England and Wales. See 2 Roundell Palmer, Memorials 445 (1896), https://hdl.handle.net/2027/uc2.ark:/13960/t6833sb9f. Cf. 13 Geo. 3 c. 21, cl. 1 (describing those within the Act of Ann. as "intitled to all the rights and privileges of natural-born subjects"), and W. WiLkinson, A Compleat History of the Trials of the Rebel Lords in Westminster-Hall 247 ([1749]) (Lord Chief Justice's charge to jury: "those who acted under the French King 's Commission, and not born in British Dominions, were to be esteemed as Prisoners of War") (emphasis in original), 
alternative that if the Acts did apply to Drummond, who was born and domiciled in France, then he was a British subject only in an artificial sense and not within the ordinary meaning of the words or under the law of nations. ${ }^{236}$ The Privy Council found Drummond to be in form and substance a French citizen and denied him treaty benefits due to British subjects, describing him as only "technically a British subject" and finding it "difficult to believe" that Britain would have executed him for treason if it had captured him fighting against it on the side of the French. ${ }^{237}$

Yet this cannot entirely explain the inconsistencies in English and British law and practice. Coke's report in Calvin's Case explains that birth within the dominions and allegiance of the king "naturalized" Calvin by procreation, ${ }^{238}$ and George II pardoned a natural born subject convicted of treason after the jury recommended mercy because he had been removed from Britain in his early infancy and had thereafter resided entirely abroad. ${ }^{239}$

\section{CONCLUSION}

The Supreme Court's controlling precedents and American constitutional history are consistent with the applicable eighteenth century British rule of construction, the standard British interpretation of the common law rule of nationality "by birth," the British characterization of a subject's foreign-born children as aliens by nature, and the non-transmission of nationality. In particular, they are consistent with Leslies v. Grant and the Act of Geo. III, the only two apparent controlling authorities interpreting the effect of the Acts on natural born status that pre-date the Constitution. Consequently, only a morally and politically justifiable living or responsive theory of constitutional interpretation can grant derivative citizens eligibility to the presidency. ${ }^{240}$

https://hdl.handle.net/2027/nnc1.cu54371317. But cf. The Trial of George Busby at Derby Assizes, for High Treason, being a Romish Priest (1681), 8 St. Tr. 525, 534 (Assiz.) (rejecting claim that a similar post-natal naturalization statute granted privileges without imposing penalties in a case involving an offspring who had moved to England).

236 See Drummond's Case, 12 Eng. Rep. at 496-97 (argument of King's Advocate) and 500 (Wynford, V.C.) (domicile).

237 Id. at 500 (Wynford, V.C.). Contrast the guardianship cases Hope and Willoughby, discussed supra note 225, finding that children born and living abroad were entitled to the rights of natural born subjects under the Acts without qualification and without regard to their foreign residence, foreign law, the law of nations, and the courts' inability to enforce their guardianship orders abroad.

238 See Calvin's Case (1608) 7 Co. Rep. 1a, 14b.

239 See Proceedings against Aeneas Macdonald (1747) 18 St. Tr. 858, 860, https://hdl. handle.net/2027/pst.000018429084, and KeTTNER, supra note 22, at 51. The king also pardoned the post-natally naturalized George Busby; the case report does not provide the reason. See Busby, 8 St. Tr. at 550.

$240 C f$. Lord Ellesmere's opinion in Calvin's Case:

[S]ome laws, as well statute law as common law, are obsolete and worn out of use: for, all human laws are but leges temporis: and the wisdom of the judges found them to be unmeet for the time they lived in, although very good and necessary for the time wherein they were made. And therefore it is said "leges humanae nascuntur, vigent, et moriuntur, et habent ortum, statum, et occasum."

By this rule also, and upon this reason it is, that oftentimes ancient laws are changed 
Other English and British authorities that interpret the effects of naturalization at birth and afterward reveal deeply conflicting visions of national identity and allegiance based on characteristics like residency, gender, religion, age, and spousal heritage. They even question whether the Acts required any allegiance to Britain from birth. Those authorities do not justify departing from the American doctrinal and historical definition of a natural born citizen. Rather, they stand as an example of the difficulty of developing a coherent theory of nationality and allegiance that could justify granting presidential eligibility to derivative citizens.

\section{Natural Born Derivative Citizenship: Threshold REQuirements AND A Possible ApProACH}

Some assert that the natural born citizenship requirement is inconsistent with democratic government and is racially prejudiced given the scale and sources of contemporary immigration. ${ }^{241}$ Expanding the definition to include derivative citizens would only compound the problem. The same intense nativism and gender bias that animated British nationality statutes drove even more restrictive American derivative citizenship laws and practices that to this day reinforce traditional gender roles and include requirements deliberately enacted to reduce the number of persons gaining citizenship at birth to American parents abroad, particularly persons of Asian, Southern and Eastern European, and Mexican American heritage. ${ }^{242}$ Seven centuries of Anglo-American legal history illustrate the difficulty of reconciling derivative nationality law and practice with our highest constitutional ideals of equal protection of the law.

Any proposal to treat derivative citizens as natural born should meet the following threshold conditions. First, the derivative citizenship statutes should not discriminate against any children of any American citizens in practice or intent. They should not impose substantive or procedural conditions or constraints that favor children of some parents over those of others. Second, the proposal should be based on a theory of moral values and political allegiance that does not

by interpretation of the judges ....

Calvin's Case (1608) 2 St. Tr. 560, 674 (spelling modernized).

241 See Duggin \& Collins, supra note 65, at 137-38.

242 See, e.g., Collins, supra note 8, at 2191-95 (generally) and To Revise and Codify the Nationality Laws of the United States into a Comprehensive Nationality Code: Hearings Before the Comm. on Immigration and Naturalization on H.R. 6127 superseded by H.R. 9980, 76th Cong. 301, at 40-41 (Chinese Americans and Mexican Americans), 58 (stricter physical presence requirements in cases of mixed nationality parents), 137 ("utterly absurd" that Italian Americans and Hungarian Americans should be "breeding citizens of the United States" abroad whom the nation cannot exclude) and 41, 58, 185 (asserting that naturalization of children within the United States is "real naturalization" and that foreign-born children of certain citizens are not "really American") (1945) (statements of Richard Flournoy, Department of State), http://hdl.handle.net/2027/ mdp.39015019148942. Cf. Sasha von Oldershausen, Western Block: One Woman's Quest for Citizenship, TeXAS OBSERver (Nov. 13, 2015), https://www.texasobserver.org/ derivative-citizenship-customs-officers/ (federal procedural impediments to Mexican Americans proving derivative citizenship). 
undermine birthright citizenship inherited from the common law, incorporated in the original Constitution, and codified in the Fourteenth Amendment. Third, the federal government should respect such values and allegiance generally, not merely in presidential eligibility. The nation cannot rely on the importance of parents to justify presidential eligibility for some citizens while deporting those of natural born minors. ${ }^{243}$

One possible approach to a constitutional theory of natural born derivative citizenship may be to recognize and respect rights of the family as a unit, as its members define their family, rather than the rights of only individual members. Domestic and international law provide significant precedent for recognizing rights of family unity that could provide the moral basis for the foreign-born child's citizenship. ${ }^{244}$ The allegiance of the child to the family and of the family to the nation could provide the necessary political basis for the child's citizenship and presidential eligibility, particularly if the nation respects and protects the family as a unit in its general laws as well as in its rules of presidential eligibility. ${ }^{245}$ Such a theory might support natural born derivative citizenship without undermining birthright constitutional citizenship. Family unity can skip generations, does not require the parent to be an American citizen, and does not require a bloodline relationship. Congress has considered foreign-born grandchildren and unrelated adopted children of American citizens and resident aliens to be their "natural-born" children in order to allow the children preferential entry into the country. ${ }^{246}$

The challenges of meeting these thresholds will be great. There is no certainty that a morally and politically justifiable theory can be developed, and Congress is unlikely to yield its historical power to discriminate in derivative citizenship law. However, courts might in time reach the result by striking down discriminatory provisions of current law under a well-constructed and morally justifiable living or responsive theory of constitutional interpretation that meets the threshold conditions and thus our highest constitutional ideals of equal protection of the law.

243 Cf. Erynn Elizabeth Reitmayer, When Parents Get Deported Citizen Children Fight to Survive, ASU NEws 21 (Aug. 2010), http://asu.news21.com/2010/08/children-ofdeported-parents/ (deportation of parents of Mexican American natural born citizen minors). Contrast Non-EU parents may have EU residence right, ECJ rules, $\mathrm{BBC}$ NEWS (May 10, 2017), http:/www.bbc.com/news/world-europe-39868868.

244 See, e.g., Giovanna I. Wolf, Preserving Family Unity: The Rights of Children to Maintain the Companionship of their Parents and Remain in their Country of Birth, 4 Ind. J. Global Legal Stud. 207 (1996). Cf. Miller v. Albright, 523 U.S. 420, 472 (1998) (Breyer, J., dissenting) ("The family whose rights are at issue here . .").

245 Lord Moncreiff stated that a foreign-born child is born out of the allegiance of the British parent. See Dundas v. Dundas (1839) 12 Scot. Jur. 165, 171. A living or responsive theory might find that members of a family have allegiance to each other and consequently to the nation of the citizen member.

246 See, e.g., H. Rep. No. 2439, Relief of Certain Aliens, to accompany H. J. Res. 649, 84th Cong. 2d Sess. (June 26, 1956) at 9-10 (citizen grandparents and alien grandchild) and 12-14 (resident alien parents and adopted alien orphan). 